NBER WORKING PAPER SERIES

\title{
THE RISK OF BEING A FALLEN ANGEL AND THE CORPORATE DASH FOR CASH IN THE MIDST OF COVID
}

\author{
Viral V. Acharya \\ Sascha Steffen \\ Working Paper 27601 \\ http://www.nber.org/papers/w27601
NATIONAL BUREAU OF ECONOMIC RESEARCH
1050 Massachusetts Avenue
Cambridge, MA 02138
July 2020

We thank editors Andrew Ellul, Isil Erel, and Uday Rajan (the editors). We also thank Ed Altman, Yakov Amihud, Tobias Berg, Ruediger Fahlenbrach, Max Jager, Daniel Streitz, and Josef Zechner and seminar participants at Bank of England, CFA Society - New York, NYU Stern School of Business, and Standard \& Poor's. Christian Schmidt provided excellent research assistance. Send correspondence to Sascha Steffen, s.steffen@fs.de. The views expressed herein are those of the authors and do not necessarily reflect the views of the National Bureau of Economic Research.

NBER working papers are circulated for discussion and comment purposes. They have not been peerreviewed or been subject to the review by the NBER Board of Directors that accompanies official NBER publications.

(C) 2020 by Viral V. Acharya and Sascha Steffen. All rights reserved. Short sections of text, not to exceed two paragraphs, may be quoted without explicit permission provided that full credit, including (C) notice, is given to the source. 
The Risk of Being a Fallen Angel and the Corporate Dash for Cash in the Midst of COVID Viral V. Acharya and Sascha Steffen

NBER Working Paper No. 27601

July 2020

JEL No. G01,G14,G32,G35

\begin{abstract}
$\underline{\text { ABSTRACT }}$
Data on firm-loan-level daily credit line drawdowns in the United States expose a corporate "dash for cash" induced by the COVID-19 pandemic. In the first phase of the crisis, which was characterized by extreme precaution and heightened aggregate risk, all firms drew down bank credit lines and raised cash levels. In the second phase, which followed the adoption of stabilization policies, only the highest-rated firms switched to capital markets to raise cash. Consistent with the risk of becoming a fallen angel, the lowest-quality BBB-rated firms behaved more similarly to non-investment grade firms. The observed corporate behavior reveals the significant impact of credit risk on corporate cash holdings.
\end{abstract}

Viral V. Acharya

Stern School of Business

New York University

44 West 4th Street, Suite 9-65

New York, NY 10012

and CEPR

and also NBER

vacharya@stern.nyu.edu

Sascha Steffen

Frankfurt School of Finance \& Management

Adickesallee 32-34

60322 Frankfurt

Germany

s.steffen@fs.de 
A large literature highlights the importance of financial constraints for corporate cash holdings (Opler et al. 1999; Almeida, Campello, and Weisbach 2004; Bates, Kahle, and Stulz 2009). Researchers usually focus on the precautionary motive of financially constrained firms to hoard cash. Acharya et al. (2012) show that cash holdings are also likely endogenous to a firm's credit risk and that even some high-rated firms behave qualitatively similar to lower-rated firms that are likely more financially constrained. During economic boom periods, the determinants of cash holdings are thus difficult to isolate, particularly in the presence of abundant credit supply even for riskier firms. An important example is the case of BBB-rated firms. Since the 2008 to 2009 global financial crisis, the volume of BBB-rated debt has more than quadrupled. ${ }^{1}$ Within this rating class, credit has geared toward riskier customers with high leverage, in turn raising concerns about their possible future downgrades to non-investment-grade (nonIG) status and the associated "cliff" risk of losing access to or facing heightened costs of financing in bond and equity markets. ${ }^{2}$

The outbreak of the COVID-19 pandemic induced governments globally to shutter major parts of their economies, an action intended to curb the spread of infectious disease but that could potentially plunge a vast majority of firms into an impending liquidity crisis. COVID19 thus exogenously increased the default risk for many firms by directly affecting firms' stream of future cash flows and simultaneously increasing their rollover risk (He and Xiong 2012). ${ }^{3}$ This impact was particularly felt by BBB-rated firms, who experienced a sudden increase in the risk of being downgraded to nonIG and to become the so-called "fallen angels."

\footnotetext{
${ }^{1}$ Dealogic data suggest that during the 2015 to 2019 period alone, U.S. firms issued about US\$4.5 trillion in corporate bonds. BBB-rated firms issued US\$1.4 trillion in bonds, or about $31 \%$ of the total corporate bond volume.

${ }^{2}$ Altman (2020) estimates that about 34\% of BBB-rated firms can be classified as nonIG firms based on their zscore. Downgrading a significant number of firms to nonIG status also might arouse concerns about financial stability, because both banks (through loans) and insurance companies (through corporate bond holdings) are largely exposed to downgraded firms (e.g., Ellul, Jotikasthira, and Lundblad 2011; Chodorow-Reich, Ghent, and Haddad 2020).

${ }^{3}$ Haddad, Moreira, and Muir (2020) document that the default risk of riskier firms, but not that of safer firms, increased in early March 2020.
} 
The COVID-19-induced shock thus provides an interesting setting in which to probe the impact of credit risk on corporate cash holdings and the role of financial markets in providing immediate liquidity.

Using a novel data set of daily credit line drawdowns at the firm-loan-level during the pandemic as well as quarterly capital structure data, we study the resultant "dash for cash" among publicly listed nonfinancial firms in the United States. Do riskier firms increase cash holdings more than safer firms? How intense was the initial "dash for cash" and when did it reverse; specifically, how did the monetary and fiscal response of the Federal Reserve (Fed) and the U.S. government affect the "dash for cash"? Was the stabilization impact of these policies felt uniformly across firms of different ratings? Equally importantly, how did firms raise cash (through credit lines drawdowns, term loans, bond issuances, or equity issuances)? And, did the stock market differentially price firms based on their ex ante balance sheet and off-balance sheet liquidity relative to short-term debt? These are some of the questions on corporate and market behavior that we investigate in this paper.

\section{[Figure 1]}

Panel A of Figure 1 shows quarterly cash-to-assets ratios of U.S. nonfinancial firms since January 1, 2018, for different rating categories (AAA-A-rated, BBB-rated, nonIG, and unrated firms). Panel B of Figure 1 shows the time series of cash over cash plus undrawn credit. In both panels, we document that upon the onset of the pandemic the overall cash levels-and the preference for cash relative to bank lines of credit—rose for the whole corporate sector, and especially so for lower-rated (BBB-rated and nonIG) firms, signifying the primacy of cash in corporate liquidity management during times of heightened aggregate risk.

We show in a regression framework that, consistent with Figure 1, BBB-rated and nonIG firms increased their cash holdings between January 1 and 31 March 31, 2020 (a period we usually refer to as Q1 2020 throughout the paper), significantly more than AAA-A-rated and unrated firms, even after controlling for determinants of corporate cash holdings frequently 
used in the corporate finance literature (e.g., Bates, Kahle, and Stulz 2009; Azar, Kagy, and Schmalz 2016).

How did firms raise cash during the first quarter of 2020? We use quarterly data about firms' debt capital structure choice obtained from Capital IQ and show that firms significantly increased their leverage ratio (i.e., total debt-to-assets ratio) across all rating classes, particularly low-rated and unrated firms. We document several other interesting empirical facts. All firms drew down their credit lines, but usage rates were highest among BBB-rated and nonIG firms. AAA-A-rated firms maintained access to capital markets and raised cash through bond and equity issuances (in addition to credit line drawdowns). Some BBB-rated firms still had access to public debt but mainly increased cash holdings through credit line drawdowns and term loan issuances. NonIG and unrated firms - arguably the most constrained firms or firms experiencing the greatest rollover risk- had to rely fully on credit-line drawdowns and term loans from banks.

This quarterly data provides a window into corporate capital structure choice and is informative as to changes in a firm's balance sheet positions between two quarters; however, the consequences of the pandemic and the lockdown were visible in a compressed "time capsule" after mid-February within a matter of a few weeks. Quarterly balance sheet data might therefore mask important daily dynamics. Moreover, at the time of writing of this paper, quarterly data were only available until the end of the first quarter of 2020. We thus explore the "dash for cash" using daily drawdown data during the pandemic that is available to us also over the April to June 2020 period. Figure 2 uses daily data from the beginning of March 2020.

\section{[Figure 2]}

Panel A of Figure 2 shows the cumulative daily credit line drawdowns of U.S. nonfinancial firms. From March 5, 2020, until March 23, 2020, the day the Fed announced its corporate bond buying program, firms withdrew about US\$240 billion (bn) from outstanding credit lines. Panel B of Figure 2 shows the cumulative drawdowns by rating class. Across all 
rating categories, we document the concentrated "dash for cash" through credit line drawdowns early in the pandemic from March up to the beginning of April 2020. AAA-A- and eventually BBB-rated firms stopped drawing down credit lines, while nonIG and unrated firms relied on credit line funding until June 2020.

When comparing this credit line usage during COVID-19 to the usage during the global financial crisis (at the end of 2008), we find that the overall usage of credit drawdowns seems comparable between the two shocks. Drawdowns, however, were more clustered and the drawdown intensity was much larger in the current pandemic within a few weeks compared to 2008.

Interestingly, we find that the weighted average z-score (a commonly used measure of credit risk developed by Altman 1968) of firms that drew down credit lines increased until the beginning of April 2020 and then meaningfully declined until the end of April 2020, confirming that even higher-quality firms (i.e., AAA-A-rated firms) drew down early in the pandemic. For high-quality firms, however, other funding sources opened up eventually, whereas those firms with poor credit quality had to rely on credit lines for raising cash.

We examine this differential pattern in detail using daily bond issuances of U.S. nonfinancial firms. NonIG firms appear to have lost access to public debt market since the beginning of March 2020. BBB-rated firms issued few new bonds from the middle of February until the end of March 2020. The surge in bond issuances that started mid-March 2020 following the interventions by the Fed and the U.S. Treasury was mainly driven by AAA-Arated firms. Evidently, however, even the highest-rated firms that issued bonds during COVID19-induced stress could only do so only at substantially higher yields compared to the period before the middle of February 2020.

Importantly, we show that the "dash for cash" was overall the highest among lowquality BBB-rated firms, that is, BBB-rated firms with low z-score. These firms perform similarly to BB-rated firms after matching firms from both rating categories based on their z- 
score (possibly because BBB-rated firms are probably of worse quality than their credit rating suggests; Altman 2020). These firm therefore likely faced a downgrade if the stress worsened. Consistent with a "dash for cash" of firms that are at the risk of becoming a fallen angel, and facing the "cliff" risk of losing access to or facing heightened costs of financing in bond and equity markets, we find that BBB-rated firms drew down from their credit lines significantly more than comparable BB-rated firms. ${ }^{4}$

Taken together, therefore we find that there have been two distinct phases in the dash for cash. In the first phase of extreme precaution, firms across all rating classes, including the highest-rated investment-grade firms, drew down on their credit lines at an unprecedented pace and scale, a phase that ended only with the decisive monetary and fiscal response toward the end of March 2020. In the second phase that followed policy stabilization measures, AAA-Arated firms, that is, high-quality investment-grade firms, issued bonds as well as equity in public capital markets, particularly after the Fed initiated its corporate bond buying program and halted their credit line drawdowns. In contrast, bond issuances of BBB-rated firms, that is, the lowestrated investment-grade firms, remained mostly flat at first and only slowly accelerated with continuing support from the Fed. Issuances of sub-investment-grade firms never took off; instead, these firms took out term loans from banks or rushed to convert their credit line commitments from banks into cash accounting for about half of all the credit line drawdowns.

In our last set of tests, we assess whether the stock market rewarded firms with access to ex ante liquidity. Access to ex ante liquidity might dampen the impact of COVID-19 on the stream of future cash flows of some firms if they are better able to meet their operating expenses and maintain productive capacity during the lockdown, and also mitigating their elevated

\footnotetext{
${ }^{4}$ Consistent with this dash for cash by particularly high-risk firms, Carletti et al. (forthcoming) estimate a substantial equity capital shortfall for Italian firms as a consequence of the lockdown, particularly for firms that become distressed.
} 
rollover risk. ${ }^{5}$ We construct a measure of balance sheet liquidity of nonfinancial firms taken all these components into account, as the sum of undrawn credit lines and cash minus short-term liabilities over total assets. We show that corporates with liquidity buffers were being rewarded by stock markets upon the onset of the pandemic. However, prior to the pandemic as well as starting in April 2020 and following the liquidity interventions by the Fed and the U.S. Treasury, stock price movements were not significantly different for firms based on their liquidity.

Overall, our results highlight the important role of having access to liquidity in the financial resilience of corporations to large aggregate shocks and also reveal the significant role played by credit risk in determining corporate cash holdings.

\section{Related Literature and Data}

\subsection{Related literature}

Our paper relates to the literature that highlights a precautionary motive of more financially constrained firms to hoard cash (Opler et al. 1999; Almeida, Campello, and Weisbach 2004; Bates, Kahle, and Stulz 2009). Eisfeldt and Muir (2016) study the implications of financial constraints for the dynamics of corporate cash holdings. Acharya et al. (2012) argue that credit risk is a salient determinant of cash holdings. We find that firms with higher credit risk (i.e., nonIG and low-quality BBB-rated firms) particularly increased their cash holdings in the first quarter of 2020.

Our paper also relates to the literature on the choice between cash and lines of credit. Sufi (2009) and Disatnik, Duchin, and Schmidt (2010) show that bank lines of credit have become an important source of firm financing; they show that firms trade off using cash and bank lines of credit as a function of their idiosyncratic risk. Acharya, Almeida, and Campello

\footnotetext{
${ }^{5}$ Campello, Graham, and Harvey (2010) show that constrained firms increase credit line drawdowns, are less able to borrow externally, and reduce investments. Duchin, Ozbas, and Sensoy (2010) show that ex ante cash can help dampen credit supply shocks. Berg (2018) shows that precautionary savings can have aggregate real effects.
} 
(2013) show that firms with high exposure to systematic risk have a higher ratio of cash to credit lines and face higher costs on their credit lines. ${ }^{6} \mathrm{We}$ find consistent evidence during the COVID-19-induced shock as cash to credit line ratios increase from Q4 2019 to Q1 2020, particularly for firms with lower credit quality who might find it costlier to raise external capital. These firms were more dependent on committed bank credit lines relative to safer, for example, AAA-A-rated firms that could also issue public debt.

Finally, our paper relates to the quickly emerging literature on the effect of the COVID19 shock on the corporate sector. Halling, Yu, and Zechner (forthcoming) investigate U.S. firms' access to public capital markets and show that particularly highly rated firms issued public debt after the onset of the pandemic, but substantially less equity. Other papers consider stock price reactions to COVID-19. Stock price reactions emphasize the importance of financial policies to firm value (Ramelli and Wagner forthcoming), financial constraints and the cash needs of affected firms (Fahlenbrach, Rageth, and Stulz 2020), changing discount rates because of higher uncertainty (Gormsen and Koijen 2020; Landier and Thesmar 2020), and social distancing (Pagano, Wagner, and Zechner 2020). We show the importance of cash-even relative to bank lines of credit_during aggregate risk episodes, such as the pandemic. Moreover, we document two important phases of the COVID-19-induced shock (pre- and postFed intervention) that help us understand the relative importance of cash for firms with different credit quality and the implications of central banks' liquidity support for credit markets by differential firm credit quality. This latter evidence is consistent with the evidence in Acharya, Byoun, and $\mathrm{Xu}$ (2020a) that firms build cash reserves from external finance issuances if the

\footnotetext{
${ }^{6}$ Other papers explore the determinants of credit line drawdowns in previous crises. Ivashina and Scharfstein (2010) document an acceleration of credit line drawdowns during the 2007-2009 crisis; their evidence is consistent with ours. Berg, Saunders, and Steffen (2016) show that credit lines are more likely to be used if a borrower's economic performance deteriorates, particularly for nonIG and unrated firms. Berg et al. (2017) show that U.S. firms' drawdown behavior is particularly sensitive to the overall market return. We show that pandemic drawdowns have been more intense but similar in spirit.
} 
current cost of capital is low compared to the expected future costs in order to smooth the overall cost of capital over time.

While most papers focus on the corporate sector, a few zero in on the effects of the COVID-19 shock on the banking sector. Li, Strahan, and Zhang (forthcoming) document the largest ever liquidity demand by firms drawing down preexisting credit lines using bank regulatory filings. Banks were able to accommodate the liquidity demand due to cash inflows from the Fed and from depositors. ${ }^{7}$ Acharya, Engle, and Steffen (2020b) show how this aggregate liquidity demand is priced in banks' stock returns and how this can be incorporated in bank stress tests. We show this "dash for cash" of the corporate sector and an unprecedented pace of (precautionary) credit line drawdowns in the first three weeks of the pandemic because of a differential demand for cash of firms with different credit quality.

\subsection{Data}

To investigate the effect of credit risk on corporate cash holdings during the COVID-19 pandemic, we construct a sample of all publicly listed U.S. firms, for which financial variables are available at the end of 2019 in Capital IQ. We drop financial firms and utilities and firms with total assets below US\$100 million at the end of 2019. Our final sample comprises 1,971 U.S. nonfinancial firms.

We use different data sets in our analysis. We obtain quarterly borrower characteristics from the Compustat database and debt capital structure information as well as information on equity issuances and payouts (dividends and share repurchases) from the S\&P CapitalIQ database. Debt capital structure information includes unused (off-balance sheet credit lines), used credit lines, term loans and bonds. Bond issuance data are collected from Dealogic. Stock returns are obtained from CRSP.

\footnotetext{
${ }^{7}$ The maneuvering of this stress point stands in contrast to the global financial crisis of 2007 to 2009, during which the role of banks as liquidity provider was severely impaired until the government stepped in after the Lehman Brothers default (Acharya and Mora 2015). At the beginning of the COVID-19 pandemic, banks appear to have been better capitalized, a position that has enabled them to provide eventual liquidity to the corporate sector.
} 
Finally, we obtain information about daily credit line drawdowns from the S\&P Leveraged Commentary \& Data (LCD) database, which starts in March 2020 and is collected from SEC filings or other data sources (e.g., private equity sponsor disclosures). It includes information about the drawn amount, credit line limit, lead agent who originates the loan, time of drawdown, maturity of the credit line, narrow and broad industries (based on the S\&P industry classification), and the link to the original filing, among other information. ${ }^{8}$ These data are particularly helpful in studying the dynamics of credit line drawdowns of firms in the early stages of the pandemic. ${ }^{9}$

\section{Cash Holdings of U.S. Nonfinancial Firms}

\subsection{Methodology and descriptive statistics}

2.1.1 Methodology. We first investigate more formally which firms raised cash in Q1 2020 and trace out the quarterly changes in cash holdings that we plot in Figure 1. We use quarterly data of firms' Cash-to-asset ratios, where cash is defined as cash plus short-term investments. Following the earlier literature on firms' cash holdings (e.g., Bates, Kahle, and Stulz 2009), we estimate the following regression over the Q1 2018 to Q1 2020 period:

$$
\text { Cash }_{i t}=\alpha+\sum \beta_{\mathrm{i}} \times \mathrm{Q}_{1} 2020 \times \text { Rating }_{\mathrm{i}}+\sum \gamma_{\mathrm{i}} \times \text { Rating }_{\mathrm{i}}+\gamma^{\prime} \mathrm{Q}+\theta^{\prime} \mathrm{Y}_{\mathrm{it}-1}+\eta_{\mathrm{i}, \mathrm{t}},
$$

where Cash $_{\text {it }}$ can take one of two forms: (1) $\Delta \log \left(\right.$ Cash - to - Assets $\left._{i t}\right)$, which is the change of the natural logarithm of quarterly cash and short-term investments scaled by total assets, or (2) $\operatorname{Cash}_{i t} /\left(\mathrm{Cash}_{i t}+\operatorname{Undrawn} C L_{i t}\right)$, a frequently used measure in the literature for firms' preference for cash over bank credit lines (e.g., Sufi 2009). Rating $g_{i}$ is an indicator for each rating class ( $A A A-A, B B B, N o n I G, I G$, or Rated $), Q$ is a vector of quarter dummies, and $Y_{i t-1}$ is a vector of lagged control variables. Lagged control variables include Leverage, Book-

\footnotetext{
${ }^{8}$ While most firms have and draw from revolving credit lines, a few firms use so-called "delay draw term loan" (DDTL) facilities. We do not differentiate between loan types in our analysis.

${ }^{9}$ For the matched Capital IQ-LCD data set, we compare the difference between the quarterly drawdowns reported in Capital IQ and the total daily drawdowns of the same firm as reported in the LCD data until March 2020, and we find that the mean (median) difference is $1.4 \%(0 \%)$.
} 
to-market ratio, CapEx-to-assets, $R \& D$-to-sales, and Dividend and Loss dummies. Table A1 in the appendix defines all control variables, which are constructed based on earlier literature. $\eta_{i}$ is a firm fixed effect.

Table 1 summarizes these variables. For example, the mean change in Cash-to-asset is 0.02 with a standard deviation of 0.64 , and the mean of $\operatorname{Cash}_{i t} /\left(\operatorname{Cash}_{i t}+U n d r a w n C L_{i t}\right)$ is $54 \%$. The average firm has a leverage ratio of $31 \%$ and a book-to-market ratio of 0.52 . Fortyfour percent of all firms are rated; $25 \%$ have a nonIG rating; and 19\% of firms have an IG rating. Thirteen percent are $\mathrm{BBB}$ rated, and $6 \%$ have a $\mathrm{AAA}-\mathrm{A}$ rating.

[Table 1]

2.1.2 Results. Table 2 reports our regression results. Our dependent variable is $\Delta \log \left(\right.$ Cash $_{-}$to - Assets $\left._{i t}\right)$ in columns 1 to 3 . In each column, we sequentially introduce interaction terms of a dummy variable for $Q 12020$ with Rating $_{i}$. The individual rating classes are included, but not shown for brevity. ${ }^{10}$

\section{[Table 2]}

The quarterly dummy variables show the significant increase in $\Delta \log (\operatorname{Cash}-$ to assets) in Q1 2020, which is 31\% [=exp(0.2701) - 1] larger compared to Q2 2018 (the omitted group) as shown in column 3. Importantly, the increase is mainly driven by nonIG and BBBrated firms. NonIG (BBB-rated) firms increased their cash-to-asset ratios in Q1 2020 by $18.7 \%$ (21\%) more relative to unrated firms. Overall, we observe a significant increase in cash holdings for all firms between Q4 2019 and Q1 2020.

Our dependent variable is $\operatorname{Cash}_{i t} /\left(\operatorname{Cash}_{i t}+\right.$ Undrawn $\left.C L_{i t}\right)$ in columns 4 to 6 . We use the same interaction terms and control variables, but add a one-quarter lagged beta of the firm with the S\&P 500. ${ }^{11}$ We find that riskier firms have a preference for cash over bank lines

\footnotetext{
${ }^{10}$ As shown in Figure 1, financially constrained (i.e., unrated) firms have higher cash holdings. Among rated firms, the importance of cash over rating classes seems U shaped, with AAA-A-rated and nonIG firms holding more cash (confirming the pattern in Acharya et al. 2012).

${ }^{11}$ Acharya, Almeida and Campello (2013) and Berg et al. (2017) highlight the sensitivity of credit line drawdowns to systematic risk.
} 
of credit in Q1 2020, controlling for overall liquidity. Riskier (i.e., nonIG) firms increase this ratio by 6.71 percentage points (pp) more compared to unrated firms, which is about twice compared to the average firm on our sample.

\subsection{How do firms raise cash?}

How do firms increase cash in Q1 2020? We use quarterly debt capital structure data from CapitalIQ and investigate changes in different debt capital structure components from Q4 2019 to Q1 2020. Specifically, we inspect the following: (a) drawn credit lines (Drawn CL/assets), (b) credit line usage (Drawn CL/(Drawn CL + Undrawn CL)), (c) bond debt (Bond debt/assets), and (d) term loans (Term loans/assets). We also delve into whether some firms were able to issue equity during this quarter. Table A1 in the appendix defines all capital structure variables.

2.2.1 Descriptive evidence. In panel A of Table 3, we provide differences-in-mean tests to show how, on average, the different debt capital structure components have changed between Q4 2019 and Q1 2020, in the full sample of firms and separately in each rating class.

\section{[Table 3]}

We document that the increase in cash has been funded with a significant increase in debt. On average, firms increased Total debt/assets by $2.4 \mathrm{pp}$, which is about $7 \%$ relative to the mean Q4 2019 Total debt/assets ratio. Interestingly, this is particularly driven by low-quality (nonIG) and unrated firms.

Higher-quality firms relied more on bond debt finance and less on credit lines or term loans already in Q4 2019 and this pattern has solidified in Q1 2020. That is, AAA-A- and BBBrated firms somewhat increased bond debt relative to total assets (both type of firms also significantly drew down their credit lines, particularly BBB-rated firms, which increased their usage rates by $16.5 \mathrm{pp}$ ). BBB-rated firms also increased their reliance on term loans as part of their debt capital structure. NonIG firms did not access public debt markets and, evidently, also term loans relative to total assets somewhat declined. Their cash increase was funded mainly through drawdowns of credit lines. Usage rates increased by about $26.5 \mathrm{pp}$ relative to the 
previous quarter. Similarly, also unrated firms substantially increased usage rates of credit lines. Across all firms, we find an increase in the preference for cash over bank lines of credit between Q4 2019 and Q1 2020, but particularly for firms with higher credit risk.

2.2.2 Methodology. We test this empirically using the following OLS regression specification:

$$
\text { Leverage }_{i}=a_{i}+a_{k}+\beta \text { Rating }_{i}+\theta^{\prime} Y_{i t-1}+\varepsilon_{i} \text {. }
$$

We use different proxies for Leverage to examine both levels (in Q1 2020) and changes (between Q4 2019 and Q1 2020) of different debt capital structure components as will be described in more detail below. $Y$ is a set of firm characteristics that determine a firm's demand for debt: we include firm size, measured as the natural logarithm of total assets; firm profitability, which we measure as EBITDA over total assets; tangible assets of the firm; and the market-to-book ratio (e.g., Faulkender and Petersen 2006; Sufi 2009). All control variables enter our regression with a one-quarter lag. $\mathrm{a}_{\mathrm{k}}$ is a two-digit industry fixed effect. These fixed effects account for shocks for a narrowly defined industry group (two-digit SIC codes) that might affect a firm's choice of debt. Standard errors are heteroscedasticity robust.

2.2.3 Results. In panel B of Table 3, we investigate the differences in levels of different debt structure components in Q1 2020 across rating classes. Leverage thus takes the following form: Drawn CL/assets, Bond debt/assets, or Term loans/assets. The results broadly mirror the descriptive evidence presented in panel A of Table 3. Drawn credit line-asset-ratios are significantly lower, the higher the rating class. Similarly, bond-debt dependence is larger for firms with higher ratings. Term loan dependence is larger for lower-rated and unrated firms, and nonIG firms have the largest term loan-to-asset ratios. We also use Equity issuance/assets and Payouts/assets (all measured in Q1 2020) as dependent variables. AAA-A-rated firms issued more equity in Q1 2020 compared to firms in all other rating classes, followed by BBBrated firms. That is, these firms are able to fund some of their cash increases by issuing common or preferred stock. Payouts, measured as the sum of share repurchases and dividend payments, 
is cash reducing, and only capital-market-dependent, investment-grade firms were able to payout cash to their shareholders.

In panel $\mathrm{C}$ of Table 3, we investigate changes in the volume of different debt structure components between Q4 2019 and Q1 2020 (scaled by lagged total assets) across rating classes. Leverage thus takes the following form: $\triangle$ Drawn $C L /$ Assetst-1, $\triangle$ Credit lines usage, $\Delta B$ Bond debt/assets $_{t-1}$ and $\Delta$ Term loans/assetst-1. This table shows a clear and very intuitive result: bankdependent firms raise cash through changes in bank credit (either drawing down credit lines or issuing term loans), while capital-market-oriented firms (i.e., those with an investment-grade rating) issue debt. For example, AAA-A-rated firms drew down credit lines significantly less than did firms from all other rating classes. The increase in drawn credit line volume relative to total assets of AAA-A-rated firms is about $0.9 \mathrm{pp}$ less compared the increase of unrated firms. NonIG firms, in contrast, increased credit line drawdowns relative to total assets by about $1 \mathrm{pp}$ more compared to unrated firms (column 1). The change in credit line usage supports this interpretation (column 2). AAA-A-rated firms, however, issued significantly more bonds when compared to BBB-rated firms (column 3) but fewer term loans (column 4).

Overall, our results suggest that the increase in cash documented in Section 2.1 is mainly financed with an increase in debt. While AAA-A-rated firms, that is, high-quality investmentgrade firms, were able to use public debt and equity capital markets, all other firms had to rely on bank debt to fund the necessary increase in cash during the pandemic. Importantly, and across all rating classes, we observe a significant increase in the reliance on credit lines as part of their debt capital structure and a preference for cash over bank lines of credit in managing liquidity.

\section{Dash for Cash and the Risk of Being a Fallen Angel}

As shown in Figure 2, the "dash for cash" through credit line drawdowns was concentrated very early in the pandemic, that is, in March up to the beginning of April 2020. Changes in quarterly 
balance sheet debt capital structure components might not capture important dynamics related to the cash needs of firms during the early stages of the pandemic. We thus explore the "dash for cash" using daily drawdown data during the pandemic that is available to us also over the April to June 2020 period.

\subsection{Dash for cash at the beginning of the pandemic}

Figure 2 shows that firms from all rating classes used credit lines, but particularly unrated and nonIG firms were using credit lines earlier than others. Among rated U.S. firms, BBB-rated firms drew down the most (about half of all drawdowns until March 23, 2020), followed by nonIG firms. ${ }^{12}$ Even AAA-A-rated firms used credit line drawdowns, albeit with only comparably small dollar amounts and clustered at the beginning of the pandemic in early March 2020, nevertheless underscoring that this was a phase of extreme precautionary corporate behavior. Unrated firms even drew down more compared to AAA-A-rated firms (which is further magnified if scaled by assets as unrated firms are substantially smaller). In this subsection, we investigate the intensity of these drawdowns focusing on the March to April 2020 period, when most drawdowns occurred. ${ }^{13}$

We first analyze daily drawdown intensities (i.e., daily borrowing amounts relative to a firm's credit line limit on this day). Panel A of Figure 3 shows the percentage drawdowns for the full sample of firms, and panel B shows this for each rating category. The full sample figure shows a significant decline in drawdown intensity, a result that extends broadly to all rating categories. That is, at the beginning of the COVID-19-induced shock, arguably when uncertainty was at its peak, we observe a "run" on bank credit lines with firms almost fully using their credit lines. Importantly, drawdown intensities decrease less for firms with higher

\footnotetext{
${ }^{12}$ We observe a spike in drawdowns on April 1, 2020, that might be related to quarter-end reporting or specific debt contract requirements.

${ }^{13}$ Based on S\&P industry classifications, the three broad sectors accounting for more than $60 \%$ of all credit line drawdowns in March and April 2020 are Consumer Discretionary, Industrials, and Information Technology (about US\$213bn in total). These are firms in the automotive, hotels \& gaming, aerospace and defense, and airline industries. Firms in the healthcare and utilities/energy sector drew down the least amount of credit. Companies with the largest drawdowns are General Motors, Ford, and Boeing, which together drew down 13\% of the total drawdown amount.
} 
credit risk consistent with a precautionary demand for cash at the beginning of the pandemic across all rating classes. While the precautionary demand attenuated for AAA-A, the highestquality firms, already in March 2020, it persisted among the high-risk firms, where drawdown intensities were still elevated at the end of April 2020.

\section{[Figure 3]}

How do these drawdowns compare to previous recession periods? In Acharya and Steffen (2020), we outline stress scenarios for banks with respect to expected credit line drawdowns. In one scenario, we use the end of 2008 (global financial crisis, GFC henceforth) drawdown rate, immediately after the failure of Lehman Brothers in September 2008. We use the GFC stress-scenario drawdown rates (which are based on end-of-2008 realized drawdowns) for different rating classes to calculate an expected volume of credit line drawdowns. We then compare this estimate to the actual U.S. dollar amount of credit line drawdowns since the beginning of March 2020. Table 4 shows this comparison expressed in millions of U.S. dollars.

\section{[Table 4]}

As we earlier observed in Figure 2, U.S. firms have drawn down US\$298bn from outstanding credit lines in March 2020 (and US\$39bn in April 2020). Out of this aggregate amount, the lion's share of US\$239bn (i.e., more than $80 \%$ ) was drown by BBB-rated and nonIG firms in March 2020. Interestingly, and comparing COVID-19 drawdowns to those observed during the GFC, we find that the credit line usage of BBB-rated (about 30\%) and nonIG (about 33\%) firms is even larger compared to the GFC. However, and in contrast, AAAA-rated and unrated firms draw down less compared to what we would have expected based on pervious crisis episodes. ${ }^{14}$ In other words, low-quality firms have rushed to drawn down credit

\footnotetext{
${ }^{14}$ This is consistent with our results from Section 2. AAA-A-rated firms use other forms of credit (e.g., bond and equity issuances) to raise cash. Unrated firms, however, have limited external finance options. They have sufficient cash on their balance sheets to decide not to use their liquidity insurance; they raise cash through loan issuances in the loan market; or they rely on trade credit. As such, working-capital-related loan issuances have been muted since March 2020.
} 
lines in an unprecedented scale and, consequently, banks' loan portfolios have expanded by US\$269bn in borderline investment-grade and nonIG debt in March and April 2020.

\subsection{Drawdowns and borrower risk}

To gain a better understanding of the risks associated with the credit line usage, we use the zscore as a firm-specific measure of credit risk that allows us to compare the risk of default of firms within and across rating classes when they draw down credit lines. In other words, we want to study the relation between firm-specific credit-line usage and firm-specific default risk across rating categories on a specific day and over time within a rating class.

\section{[Figure 4]}

Panel A of Figure 4 plots drawdown intensities (left-hand scale) together with their zscore (right-hand scale) for the full sample of firms. ${ }^{15}$ The average quality of borrowers improves during March until the beginning of April 2020 and then significantly declines reaching its lowest value at the end of April 2020. At the beginning of this stress period, also high-quality (AAA-A- and BBB-rated) firms participated in this dash for cash, either for precautionary purposes or because credit lines were a relatively cheaper funding option when public debt was more difficult to issue and/or only at high yields.

Panel B of Figure 4 plots the average across firms of credit-line drawdown intensities (left-hand scale) together with their z-score (right-hand scale) for each rating group on a given day. Somewhat surprisingly, unrated firms appear to be less risky than both BBB-rated and nonIG firms. In all rating categories, we observe that the average quality of borrowers improves during March until the beginning of April 2020. Importantly, those firms that continue to use their credit lines toward the end of the sample period, appear to be, on average, riskier, consistent with the importance of credit risk for corporate cash holdings. High-quality firms might have been able to issue bonds in public capital markets, an issue we investigate next.

\footnotetext{
${ }^{15}$ We use a smoothing function to plot the $\mathrm{z}$-score estimates.
} 
Overall, high-quality investment-grade firms, particularly AAA-A-rated and also BBBrated firms, that is, firms that are usually capital market oriented, drew down their credit line with high intensity in March until the beginning of April. Riskier (i.e., nonIG) firms and more financially constrained (i.e., unrated) firms were limited in accessing public debt markets and continued to rely on credit lines throughout April with, on average, a higher drawdown intensity. A possible interpretation is that interventions by the Fed and the U.S. Treasury facilitated the access of public debt markets for the highest-quality firms, an issue we investigate in the next subsection.

\subsection{The impact of interventions by the Fed on bond market access}

\subsubsection{Corporate bond issuances during the COVID-19 pandemic.}

In Section 2, we have documented that particularly AAA-A-rated firms raised cash by issuing public bonds between Q4 2019 and Q1 2020. To determine which firms accessed public debt markets during the early phase of the pandemic, we use daily corporate bond issuance data for U.S. firms obtained from Dealogic.

3.3.1.1 Corporate bond volume. Figure 5 plots the cumulative bond issuance volume (solid line, left-hand axis) and each day's average yield to maturity of newly issued bonds (dotted line, right-hand axis) for the January 1 to June 30, 2020, period, for the full sample in panel $\mathrm{A}$ and by rating class in panel $\mathrm{B}$ (note that all bond issuers are rated, i.e., there is no "unrated" category). The vertical line represents the Fed's announcement of the corporate bond buying program on March 23, 2020. We discuss the effect of the actions taken by the Fed and the U.S. government in the next subsection.

[Figure 5]

In total, U.S. nonfinancial firms issued about US\$150bn in public bonds until midFebruary. From this point onward, issuance volume was muted until mid-March as spreads in 
the investment-grade and high-yield market were elevated. From mid-March until the end of April 2020, however, issuance volume increased from about US\$180bn to US\$545bn. ${ }^{16}$

The evidence in panel B of Figure 5 suggests that the cumulative bond issuance volume of BBB-rated firms was flat from the middle of February until March 23, 2020; that is, they issued few new bonds until the Fed announced the corporate bond buying program. The surge in bond issuances that started after March 15, 2020, was thus (at first) primarily driven by AAAA-rated firms. NonIG firms have lost access to public debt markets since the beginning of March 2020; between March 4 and March 30, there has not been a single nonIG bond issue.

3.3.1.2 Corporate bond yields. Panel A of Figure 5 already suggests that firms that issued bonds during the COVID-19-induced stress period could only do so at substantially higher yields compared to the period before middle of February (as the dotted line suggests). Panel C of Figure 5 plots the difference between the yield-to-maturity (YTM) of newly issued corporate bonds between BBB- and AAA-A-rated firms and nonIG and BBB-rated firms. Evidently, the YTM of riskier bonds is increasing over the January 1, 2020, to June 30, 2020, period relative to safer firms, that is, it becomes costlier, particularly for nonIG firms, to issue bonds in public debt markets.

Overall, the difference between issuance volume and YTM of BBB-rated and nonIG firms emphasizes the "cliff" risk of losing access to or facing heightened costs of financing in bond markets when firms are downgraded to a nonIG rating.

\subsubsection{Fed's interventions.}

3.3.2.1 Interventions. In an effort to ameliorate the COVID-19-induced stress on the economy and the associated stress on financial markets, the Fed and the U.S. Treasury introduced a series of stabilization measures. After reducing the Fed's fund rate close to zero and reinstating its Treasury and agency mortgage-backed securities (MBS) quantitative easing program, the Fed

\footnotetext{
${ }^{16}$ We exclude the bond issuance of about US\$20bn on April 2, 2020, by T-Mobile to finance the Sprint merger.
} 
mounted a series of programs. On March 15, it announced, among others, the Commercial Paper Funding Facility (CPFF), the Primary Dealer Credit Facility (PDCF), and the Money Market Mutual Fund Facility (MMFF). On March 17, it announced a US\$5tn repurchase program. On March 23, Fed introduced two facilities to support credit supply to large firms, the Primary Market Corporate Credit Facility (PMCCF) and the Secondary Market Corporate Credit Facility (SMCCF), through which the Fed can purchase investment-grade corporate bonds. On March 25, the Senate voted for a US\$2tn fiscal package (that was approved by the House on March 27).

While the Fed targeted short-term funding markets with its earlier initiatives, the corporate bond buying program that was announced on March 23, 2020, likely affects longterm corporate funding options. This should be particularly valuable for BBB-rated and nonIG firms that have been, up to this point, constrained to borrow in public capital markets as documented above. To assess this empirically, we study the effect of the announcement of the corporate bond buying program on stock and loan market returns. A dearth of access to liquidity was likely an important driver of firms' stock price decline at the beginning of the stress period, and alleviating funding problems might help reverse this trend. ${ }^{17}$ Moreover, the secondary loan market is an important indicator for funding stress in corporate debt markets (Saunders et al. 2020). ${ }^{18}$

3.3.2.2 Interventions and loan/stock returns and drawdowns. Panel D of Figure 5 plots stock and loan market returns. Also, that loan market returns fell about $20 \%$ since the beginning of January 2020 indicates the lack of supply of credit to firms. Both stocks and loans significantly increased after the announcement of the corporate bond buying program on March 23, 2020. Stock (loan) market returns increased by about $10 \mathrm{pp}(5 \mathrm{pp})$ after the announcement,

\footnotetext{
${ }^{17}$ We discuss this in more detail in Section 4.

${ }^{18}$ To analyze loan market returns, we use an index of about 1,500 loans issued by U.S. nonfinancial firms that are traded in the secondary loan market with a market value of about US\$1.5 trillion as of January 2, 2020.
} 
suggesting that the program might have, to some degree, reduced liquidity problems for U.S. nonfinancial firms.

However, a puzzling and counterintuitive result unfolds: when we add the cumulative credit line drawdowns since the beginning of March 2020 to the figure, we observe that, if anything, credit line drawdowns even accelerated after the Fed's announcement of the bond buying program. In contrast to an increase in stock and loan returns, our findings suggest that the funding problems of some firms persisted even after the Fed's announcements to buy investment-grade corporate bonds.

3.3.2.3 Interventions and bond issuances. Investigating corporate bond issuances around this announcement might help us understand this. In panel B of Figure 5, we show the cumulative bond issuances by rating class and a vertical line on the day of the announcement of the Fed corporate bond buying program. The impact on corporate debt markets seems to be asymmetric.

- AAA-A-rated firms: Issuance volumes of AAA-A-rated firms increased after the announcement of the CPFF, PDCF, and MMFF (March 15, 2020). Issuance volumes increased from US\$40bn to more than US\$160bn until March 23, 2020. About 75\% of all bonds during this period have been issued by AAA-A-rated firms. Until the end of April 2020, cumulative issuance volumes increased to US\$230bn.

- BBB-rated firms: The dollar volume of cumulative bond issues of BBB-rated firms was muted relative to AAA-A-rated firms before the announcement of the corporate bond purchase program. Only after March 23, 2020, issuance volumes accelerated reaching about US\$212bn at then of April 2020. Cumulative bond issuance volume of BBB-rated firms had been about $40 \%$ higher compared to AAA-A-rated firms before the start of the pandemic in March 2020. Thus, the relatively smaller increase after the Fed interventions suggests that BBB-rated firms only selectively had access to public 
debt, which is consistent with the credit line drawdown behavior of some BBB-rated firms even in April 2020.

- NonIG firms: NonIG firms were still not able to borrow in public bond markets after the Fed interventions and, therefore, continued to rely on banks, which is consistent with an additional demand for loans and drawdown of committed credit lines in the corporate loan market.

Taken together, we find that there have been two distinct phases in the dash for cash. In the first phase, firms across all rating classes, including the highest-rated investment-grade firms, drew down on their credit lines at an unprecedented pace and scale, a phase that ended only with the decisive monetary and fiscal response toward the end of March 2020. In the second phase, AAA-A-rated firms, that is, high-quality investment-grade firms, issued bonds as well as equity in public capital markets, particularly after the Fed initiated its corporate bond buying program and halted their credit line drawdowns. In contrast, bond issuances of BBBrated firms, that is, the lowest-rated investment-grade firms, initially increased issuances at a slower pace compared to AAA-A-rated firms. Issuances of sub-investment-grade and unrated firms never took off; instead, these firms continued to convert their credit line commitments from banks into cash accounting for about $65 \%$ of all the credit line drawdowns in April 2020.

\subsection{Dash for cash of fallen angels}

\subsubsection{Stock price performance of BBB- versus BB-rated firms.}

Since the 2008 to 2009 global financial crisis, the volume of BBB-rated debt has more than quadrupled. Within this rating class, credit geared toward riskier customers with high leverage, raising concerns as to whether its rating meaningfully reflect the risk of the company and about possible future downgrades to nonIG status. Altman (2020) estimates that about $34 \%$ of BBBrated firms can be classified as nonIG firms based on their z-score.

Rating agencies usually hesitate to downgrade a firm into nonIG territory as doing so might have severe consequences. For example, many institutional investors are limited to 
holding investment-grade debt and would be forced to sell. Moreover, the initial corporate bond buying program announced on March 23, 2020, included only the purchases of investmentgrade corporate debt. Also, borrowing costs in the loan market might increase in addition to higher collateral requirements or an increase in covenant strictness. Taken together, BBB-rated firms likely face a steep a reduction in access to credit a steep increase in their funding costs after a downgrade.

\section{[Figure 6]}

3.5.1.1 Stock price performance by rating. A deep and prolonged recession because of the economic lockdown might result in the downgrade of some these BBB-rated firms and stock market prices might already reflect the risk of being a "fallen angel." Panel A of Figure 6 plots the stock price of U.S. nonfinancial firms by rating class. AAA-A-rated companies perform much better compared to lower-rated firms. These firms have healthier balance sheets and better access to credit markets in case of liquidity needs (as shown also above). Interestingly, BBB-rated firms perform, if anything, more similar to nonIG as markets appear to be worried about the sustainability of the leverage of BBB-rated firms.

3.5.1.2 BBB-rated firms versus "fallen angels." Some firms have already been downgraded to nonIG by credit rating agencies at the end of March 2020 (so-called "fallen angels"). Based on our earlier analysis of the stock price response of BBB- versus BB-rated firms, we would expect to observe a significantly worse performance of fallen angels relative to other BBB-rated firms during our sample period. Panel B of Figure 6 compares the stock market performance of these fallen angels with other BBB-rated firms since January 1, 2020. ${ }^{19}$ Consistent with our previous discussion, fallen angels perform significantly worse, particularly since the beginning of the COVID-19 shock, where stock prices dropped by about $80 \%$ relative to their January 1, 2020, levels and did not recover.

\footnotetext{
${ }^{19}$ Fallen angels that are stock exchange listed and thus included in our data set are Apache Corporation (APA), Continental Resources (CLR), Delta Airlines (DAL), Ford (F), Macy's (M), Occidental Petroleum (OXY), and Patterson Energy (PTEN).
} 
We test this more formally and investigate the stock price performance of firms at the investment-grade boundary; that is, we compare BBB- to BB-rated firms. We use the z-score as a continuous measure to match firms from both rating classes that have very similar z-scores (and therefore similar default risk) but one firm is investment grade and the other firm is nonIG. We then simply compare their cumulative stock returns during the March 1, 2020-March 23, 2020 period.

\section{[Table 5]}

Panel A of Table 5 reports the results. Simply comparing all firms from both rating classes (without matching) shows that BB-rated firms perform worse. The average stock price drops about $61 \%$ during this period compared with a $49 \%$ drop of BBB-rated firms. However, comparing the return of those firms with similar z-score shows that the stock performance of both group firms is not significantly different from each other. The average stock market decline of the matched control (i.e., BB-rated) firms is about $54 \%$ and thus similar to the performance of BBB-rated firms.

\subsection{2 "Cliff risk" and credit line drawdowns.}

That is, the stock market performance suggests that BBB-rated firms are probably of worse quality than their credit rating suggests. These firms, therefore, might face a downgrade if the stress deepens. Thus, an interesting question to ask is whether they increase borrowing by drawing down their credit lines to avoid a downgrade and the associated steep increase in borrowing costs if a downgrade materializes.

3.5.2.1 Methodology. We analyze the cross-section of credit lines drawdowns during the March 1 to March 23, 2020, period and ask whether firms that are more likely to be downgraded to a nonIG category use their credit lines more compared to other firms. We test this empirically using the following OLS regression specification:

$$
\begin{aligned}
& \log (\text { Total drawdown })_{\mathrm{i}}=\mathrm{a}_{\mathrm{i}}+\mathrm{a}_{\mathrm{k}}+\beta^{\prime} \text { Rating }_{\mathrm{i}} \times \mathrm{z}-\text { score }_{i} \\
& +\gamma^{\prime} \text { Rating }_{\mathrm{i}}+\theta^{\prime} \mathrm{Y}_{\mathrm{it}-1}+\varepsilon_{\mathrm{i}} .
\end{aligned}
$$


For each firm, we construct a measure of total drawdowns as the natural logarithm of total drawdowns during this period (log(Total Drawdown)). This is our dependent variable. Our explanatory variables include indicator variables for each rating class and their interaction with the $z$-score as our measure of credit quality $\left(\right.$ Rating $_{\mathrm{i}} \times \mathrm{z}-$ score $\left._{i}\right)$. BBB-rated firms with a higher $z$-score have lower default risk. In column 1 of panel B, we add the $z$-score as control variables in addition to industry fixed effects $\left(a_{k}\right)$ defined as S\&P industry classification provided by LCD. We do not add other balance sheet characteristics $(Y)$, as the z-score is constructed from these measures.

3.5.2.2 Results. Panel B of Table 5 reports the results. Using the full sample of firms, we find that, as expected, BBB-rated firms with a higher likelihood of being downgraded (i.e., a lower z-score) rely on their credit lines to a higher degree compared to safer firms.

We then perform a propensity score matching and exclusively focus on BBB- and BBrated firms. We match these firms two different ways using (1) only Altman's z-score and (2) using a set of firm characteristics that explains both the default risk (a BBB rating vs. a BB rating) and the outcome variable (i.e., credit line drawdowns). Firm characteristics include the following: $\log$ (Market Assets), ${ }^{20}$ MTB, Debt/EBITDA, Undrawn CL, Debt/assets, Current ratio, and Tangible assets/assets. That is, we focus on a set of firms that are most similar in terms of their characteristics (such as default risk) and only differ as one firm is investment grade and the other firm is nonIG.

Columns 2 to 4 report the results, and we compare differences in credit line drawdowns in the matched sample (columns 3 and 4) to the unmatched sample (column 2). Consistent with a "dash for cash" of firms that are at risk of becoming a fallen angel, we find that BBB-rated firms draw down significantly more than comparable, BB-rated firms, even in the unmatched sample. We first match BBB- and BB-rated firms based on their respective z-score matching 1

\footnotetext{
${ }^{20}$ We use (quasi-) market assets, defined as total assets minus book equity plus market equity, as the size variable, because it is a better measure to compare BBB- and BB-rated firms because of the substantial decline in the equity prices of low-quality BBB-rated firms.
} 
treatment (i.e., BBB-rated firm) to many possible control group (i.e., BB-rated) firms. We thus use a frequency weight that weights the control group observations based on their propensity score to obtain the closest match possible (thus, the number of control group firms matches the number of treatment firms).

As expected, the difference in credit line drawdowns is even more pronounced in the matched sample (column 3). When we add other covariates improves the match and naturally produces economically somewhat smaller coefficient estimates (column 4). This is likely the most conservative approach, but the point estimate is still statistically highly significant. The coefficient suggests that matched BBB-rated firms draw down, on average, $88 \%$ more from their credit line compared to similar BB-rated firms during our sample period. ${ }^{21}$

\section{Balance Sheet Liquidity and Stock Market Performance}

\subsection{Potential real effects of the COVID-19 pandemic}

In our last set of tests, we evaluate whether the stock market rewarded firms with access to ex ante liquidity through either cash or committed lines of credit from banks relative to their shortterm debt. If access to (committed) sources of liquidity helps firms better weather this unexpected shock, stock prices should reflect this, and the stock price performance of these firms should be better than those firms that have secured ex ante access to liquidity.

We construct a new measure of balance sheet liquidity of firms that includes the following components:

- Unused credit lines: The sum of undrawn revolvers, undrawn credit lines as backup for commercial paper, and undrawn term loans.

- Cash and short-term investments: The sum of cash and short-term investments.

\footnotetext{
${ }^{21}$ While drawing down on a credit line might send a signal to rating agencies about the deteriorating credit quality of the borrower, in an aggregate shock-like the one U.S. firms experienced in early March-firms across all rating classes (also among the highest-quality firms) draw down credit lines as, for example, the quality of a bank's credit commitment might deteriorate with the quality of the bank.
} 
- Short-term debt: The current portion of debt.

Hence, we construct a comprehensive measure of firm liquidity as

Liquidity $=\frac{\text { Unused credit lines }+ \text { cash and short term investments-short term debt }}{\text { Total assets }}$.

4.1.1 Descriptive evidence. Panel A of Figure 7 shows the time series of Liquidity as well of its components (all scaled by total assets). ${ }^{22}$

[Figure 7]

In panel B of Figure 7, we split firms into those with high (low) balance sheet liquidity and plot the stock price differential of both types of firms since January 1, 2020. Stock prices of firms with access to ex ante on- or off-balance-sheet liquidity persistently outperformed those of firms that lack access to liquidity by up to 10 pp starting at the end of February 2020.

4.1.2 Methodology. To test whether firms are rewarded for having access to ex ante balance sheet liquidity, we run the following cross-sectional regressions:

$r_{i}=\alpha+\gamma \times$ Liquidity $_{i}+\beta^{\prime} Y_{i}+\varepsilon_{I}$,

where $r_{i}$ is a firm's stock return, Liquidity is the balance sheet liquidity measure (or the individual components as described above) and $Y$ is a vector of firm characteristics that have been shown to affect stock returns: $\log$ (Market Cap), Book-to-Market Ratio, Equity Beta, Profitability and Momentum. Table A1 in the appendix defines all variables.

Table 6 provides summary statistics. Panel A of Table 6 shows the mean of Liquidity and its components by rating class. Intuitively, lower-rated and unrated firms, those that are arguably more financially constrained, have higher ex ante balance sheet liquidity compared to AAA-A-rated firms.

\footnotetext{
${ }^{22}$ Consistent with the descriptive evidence presented above, corporate cash-to-assets ratios (undrawn credit lineto-assets ratios) increased (declined) in Q1 2020.
} 
[Table 6]

We provide summary statistics for stock returns (reported as log-returns) and balance sheet characteristics of our sample firms in panel B of Table 6. The average stock return of U.S. nonfinancial firms over the January 1 to March 23, 2020, period was $-45 \%[=\exp (-0.6)-1]$. While average stock returns were already negative in January and February 2020 (-4.9\% and 9.5\%, respectively), stock prices dropped by about 36\%, on average, in March 2020 .

4.1.3 Results. Table 7 reports the results of the cross-sectional regression. Our dependent variable is a firm's stock return over the January 1 to March 23, 2020, period (column 1) and for the individual months January (column 2), February (column 3), March 1-23 (column 4), and April (column 5). ${ }^{23}$

\section{[Table 7]}

Over the full sample period, we find that ex ante balance sheet liquidity of firms is priced in the cross-section of stock returns. A one-standard-deviation increase in Liquidity increased stock returns by $12.2 \%$. When we run the regression on a monthly basis, we find that balance sheet liquidity was not priced in January 2020, but was, to some extent, in February 2020 and particularly in March 2020, when the coefficient almost quadruples. After the Fed's interventions and as of April 2020, Liquidity was not a significant driver of stock returns, consistent with the Fed providing sufficient liquidity that ex ante secured liquidity through either cash or credit lines is not further rewarded.

In panel B of Table 7, we run month-to-month regressions starting in February until April 2020 (the post-Fed intervention period) including the components of our liquidity measure individually. During the February-March 2020 period, firms with ex ante more cash and short-term investments (scaled by total assets) had substantially higher stock returns, dominating the availability of credit lines in the first phase of this stress period. Also, firms

\footnotetext{
${ }^{23}$ The results are qualitatively similar when we use a beta-adjusted return as the dependent variable.
} 
with ex ante more short-term debt over total assets performed worse during March 2020. Overall, the stock market rewarded firms with access to liquidity through cash before and through bank lines of credit in after the Fed interventions, highlighting their important role in corporate financial resilience to large aggregate shocks. ${ }^{24}$

\subsection{Global financial crisis (2007-2009) versus the COVID-19 pandemic}

How does COVID-19 compare to the global financial crisis of 2007-2009 (GFC)? While the GFC also featured an aggregate demand for credit lines (Ivashina and Scharfstein 2010), firms drew down at a much smaller pace and over a longer time horizon compared to the current stress period. To understand whether firms with ex ante access to liquidity through cash or committed lines of credit also performed better during the GFC, we construct Liquidity as of Q4 2006, and Figure 8 plots the stock returns of firms with high (low) Liquidity over the 2007 to 2009 period. Consistent with our evidence during the COVID-19 pandemic, the stock prices of firms with access to ex ante on- or off-balance-sheet liquidity persistently outperformed those of firms that lack access to liquidity.

\section{[Figure 8]}

In Table 8, we run month-by-month regressions starting in Q1 2007 until Q2 2009 and use the Liquidity measure in panel A. Again, firms seem to be rewarded for having access to ex ante balance sheet liquidity in aggregate economic downturns. Consistent with Figure 8, firms with more liquidity perform significantly better in Q2 2007 and, particularly, in Q3 2007, that is, in the first phase of the GFC when the asset-backed commercial paper (ABCP) market froze, as Acharya, Almeida, and Campello (2013) documents. A similar performance differential occurred in Q2 2018, before the Lehman Brothers default, and in Q1 2009. The Fed and U.S. government responded to the economic fallout of the Lehman Brothers' default with a variety

\footnotetext{
${ }^{24}$ Further cross-sectional tests show that credit lines are particularly valuable for firms with ex ante low cash on their balance sheet, firms that are more constrained, and firms with high exposure to the COVID-19 shock.
} 
of measures to support the economy, following which we do not see any pricing of liquidity in firm stock returns.

[Table 8]

\section{Conclusion}

The lockdown as a response to the COVID-19 pandemic caused a high demand for liquidity for firms affected by the crisis. Using a novel data set of daily credit line drawdowns at the firmloan-level, we provide evidence consistent a "cash for cash" of BBB-rated firms, particularly those that might be more similar in terms of credit quality to nonIG firms. The announcement of an investment-grade corporate bond buying program by the Fed did not alleviate this cliff risk of being downgraded and these firms continue to convert committed credit lines into cash.

This "dash for cash" also affects the balance sheets of banks when commitments turn into loans as banks have to fund these exposures with equity. Worse, banks usually hold additional term loan exposure to the same firms; that is, they accumulate a concentrated exposure to firms at the risk of being downgraded. Even though banks are better capitalized compared to 2007 and before the global financial crisis, the accelerated drawdowns of credit lines and provision for possible future credit losses for on-balance sheet exposures might bring them closer to the regulatory minimum capital requirement, which not only endangers their financial stability but also can constrain future intermediation with likely spillovers into the real economy. This underscores the importance of regulatory attention to bank capital levels. 


\section{References}

Acharya, V., S. Davydenko, and I. Strebulaev. 2012. Cash holdings and credit risk. Review of Financial Studies 25: 3572-3609.

Acharya, V., H. Almeida, and M. Campello. 2013. Aggregate risk and the choice between cash and lines of credit. Journal of Finance 68:2059-116.

Acharya, V., S. Byoun, and Z. Xu. 2020a. The sensitivity of cash savings to the cost of capital. Working Paper, NYU Stern School of Business.

Acharya, V., R. Engle, and S. Steffen. 2020b. What explains the crash of bank stock prices during COVID-19? The role of health, financial and oil price risks. Working Paper, NYU Stern School of Business.

Acharya, V. and N. Mora. 2015. A crisis of banks as liquidity providers. Journal of Finance 70:1-44.

Acharya, V., and S. Steffen. 2020. 'Stress tests' for banks as liquidity insurers in a time of COVID. VoxEU.org.

Almeida, H., M. Campello, and M. Weisbach. 2004. The cash flow sensitivity to cash. Journal of Finance 59:1777-804.

Altman, E. 1986. Financial ratios, discriminant analysis and the prediction of corporate bankruptcy. Journal of Finance 23:489-609.

- 2020. The credit cycle before and after the market's awareness of the coronavirus crisis in the U.S. Working Paper, NYU Stern School of Business.

Azar, J. A., J.-F. Kagy, and M. Schmalz. 2016. Can changes in the cost of carry explain the dynamics of corporate cash holdings? Review of Financial Studies 29:2194-240.

Bates, T. W., K. M. Kahle, and R. Stulz. 2009. Why do US firms hold so much more cash than they used to? Journal of Finance 64:1985-2021.

Berg, T. 2018. Got rejected? Real effects of not getting a loan. Review of Financial Studies $31: 4912-57$. 
Berg, T., A. Saunders, and S. Steffen. 2016. The total cost of borrowing in the loan market don't ignore the fees. Journal of Finance 71:1357-92.

Berg, T., A. Saunders, S. Steffen, and D. Streitz. 2017. Mind the gap: The difference between U.S. and European loan rates. Review of Financial Studies 30:948-87.

Carletti, E., T. Oliviero, M. Pagano, L. Pelizzon, and M. G. Subrahmanyam. Forthcoming. The COVID-19 shock and equity shortfall: Firm-level evidence from Italy. Review of Corporate Finance Studies.

Campello, M., J. R. Graham, and C. R. Harvey. 2010. The real effects of financial constraints: Evidence form a financial crisis. Journal of Financial Economics 97:470-87.

Chodorow-Reich, G., A. Ghent, and V. Haddad. 2020. Asset insulators. Review of Financial Studies. Advance Access published May 22, 2020, 10.1093/rfs/hhaa061.

Disatnik, D., R. Duchin, and B. Schmidt. 2014. Cash flow hedging and liquidity choices. Review of Finance 18:715-48.

Duchin, R., O. Ozbas, and B. A. Sensoy. 2010. Costly external finance, corporate investment, and the subprime mortgage crisis. Journal of Financial Economics 97:418-35.

Eisfeld, A., and T. Muir. 2016. Aggregate external financing and savings waves. Journal of Monetary Economics 84:116-33.

Ellul, A., C. Jotikasthira, and C. T. Lundblad. 2011. Regulatory pressure and fire sales in the corporate bond market. Journal of Financial Economics 101:596-620.

Fahlenbrach, R., K. Rageth, and R. M. Stulz. 2020. How valuable is financial flexibility when revenue stops? Evidence from the Covid-19 crisis. Working Paper, Swiss Finance Institute.

Faulkender, M., and M. Petersen. 2006. Does the source of capital affect capital structure? Review of Financial Studies 19:45-79.

Gormsen, N. J., and R. S. J. Koijen. 2020. Coronavirus: Impact on stock prices and growth expectations. Working Paper, University of Chicago. 
Haddad, V., A. Moreira, and T. Muir. 2020. When selling becomes viral: Disruptions in debt markets in the Covid-19 crisis and the Fed's response. Working Paper, University of California, Los Angeles.

Halling, M., J. Yu, and J. Zechner. Forthcoming. Bond and equity issuance activity during COVID-19. Review of Corporate Finance Studies.

He, Z., and W. Xiong. 2012. Rollover risk and credit risk. Journal of Finance 67:391-429. Ivashina, V., and D. Scharfstein. 2010. Bank lending during the financial crisis of 2008. Journal of Financial Economics 97:319-38.

Li, L., P. E. Strahan, and S. Zhang. Forthcoming. Banks as lenders of first resort: Evidence from the COVID-19 crisis. Review of Corporate Finance Studies.

Opler, T., L. Pinkowitz, R. Stulz, and R. Williamson. 1999. The determinants and implications of corporate cash holdings. Journal of Financial Economics 52:3-46.

Pagano, M., C. Wagner, and J. Zechner. 2020. Disaster resilience and asset prices. Working Paper, University of Naples.

Ramelli, S., and A. F. Wagner. Forthcoming. Feverish stock price reactions to COVID-19. Review of Corporate Finance Studies.

Sufi, A. 2009. Bank lines of credit in corporate finance: An empirical analysis. Review of Financial Studies 22:1057-88. 
Figure 1. Time series of cash holdings of U.S. nonfinancial firms

This figure shows the median cash-to-asset ratio (panel A) and median Cash / (Cash + Undrawn CL) ratio (panel B) of U.S. nonfinancial firms over the Q1 2018 to Q1 2020 period.

\section{(A) Cash and short-term investments over total assets}

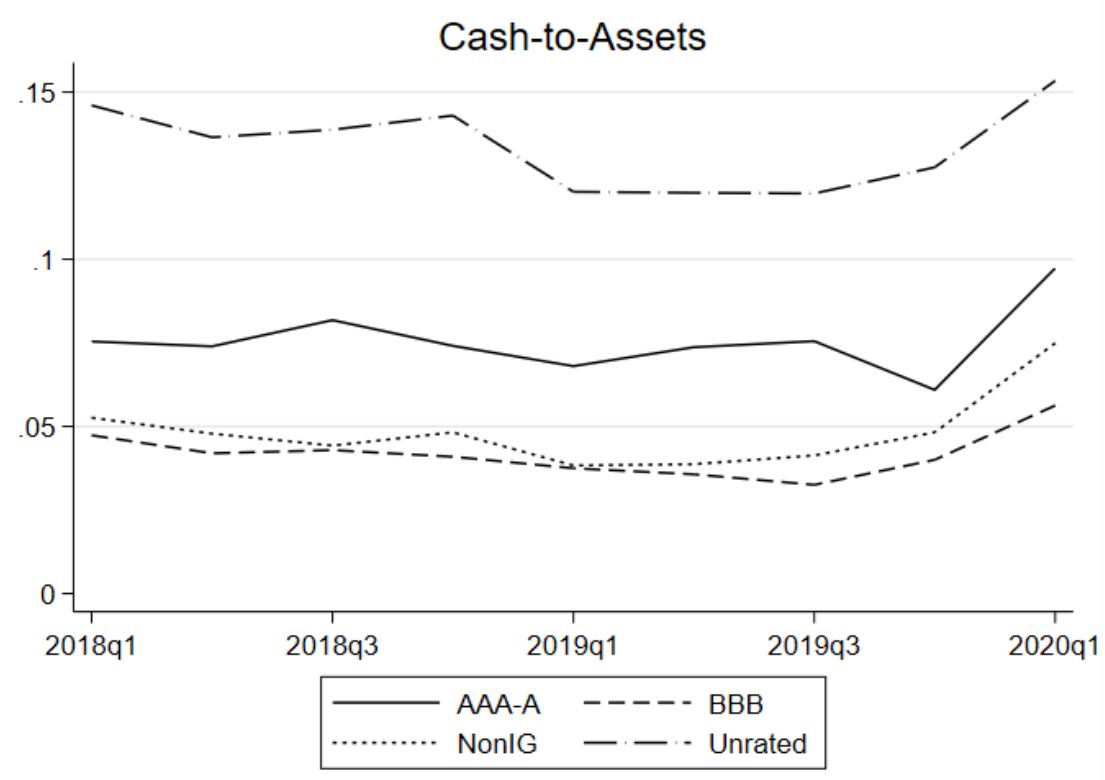

(B) Cash and short-term investments over cash and short-term investments and undrawn CL

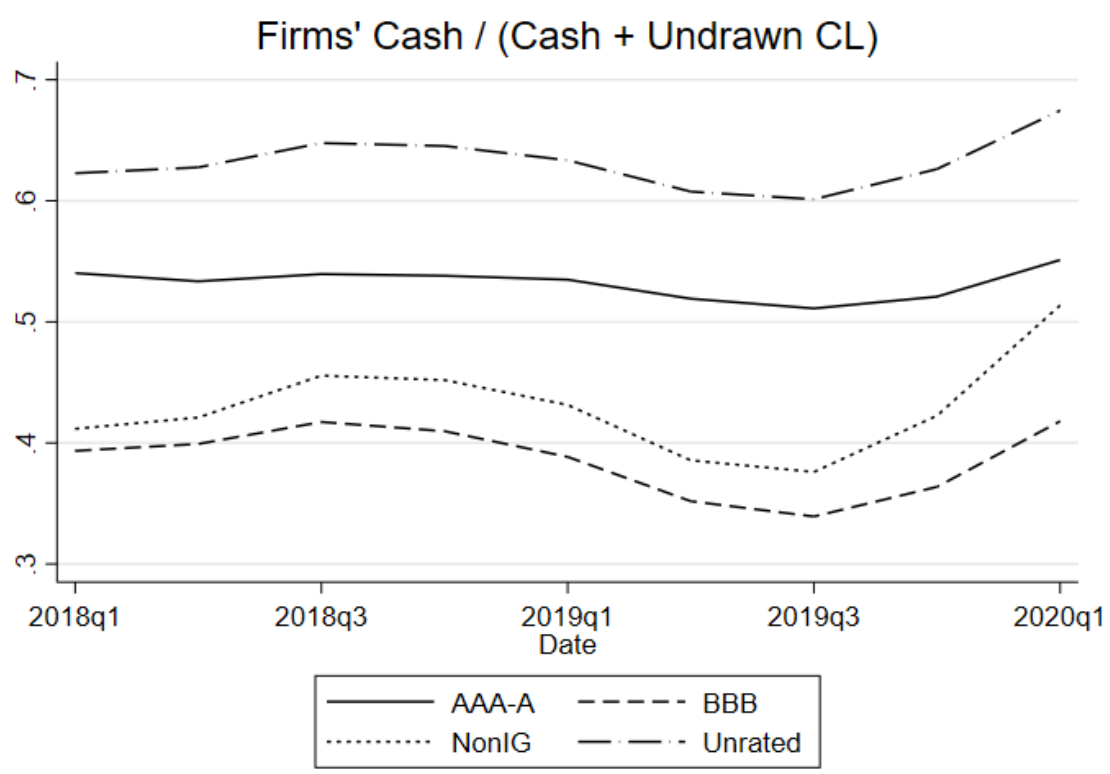




\section{Figure 2. Cumulative drawdowns}

This figure shows the cumulative daily credit line drawdowns (in billions of U.S. dollars) of U.S. nonfinancial firms over the March 1, 2020, to June 26, 2020, period (panel A) and by rating classes, that is, AAA-A-rated, BBB-rated, nonIG, and unrated firms (panel B). Panel C shows total drawdowns by rating class in March and April 2020. The vertical line represents the Fed's announcement of the corporate bond buying program on March 23, 2020.

(A) Cumulative drawdowns (in billions of U.S. dollars)

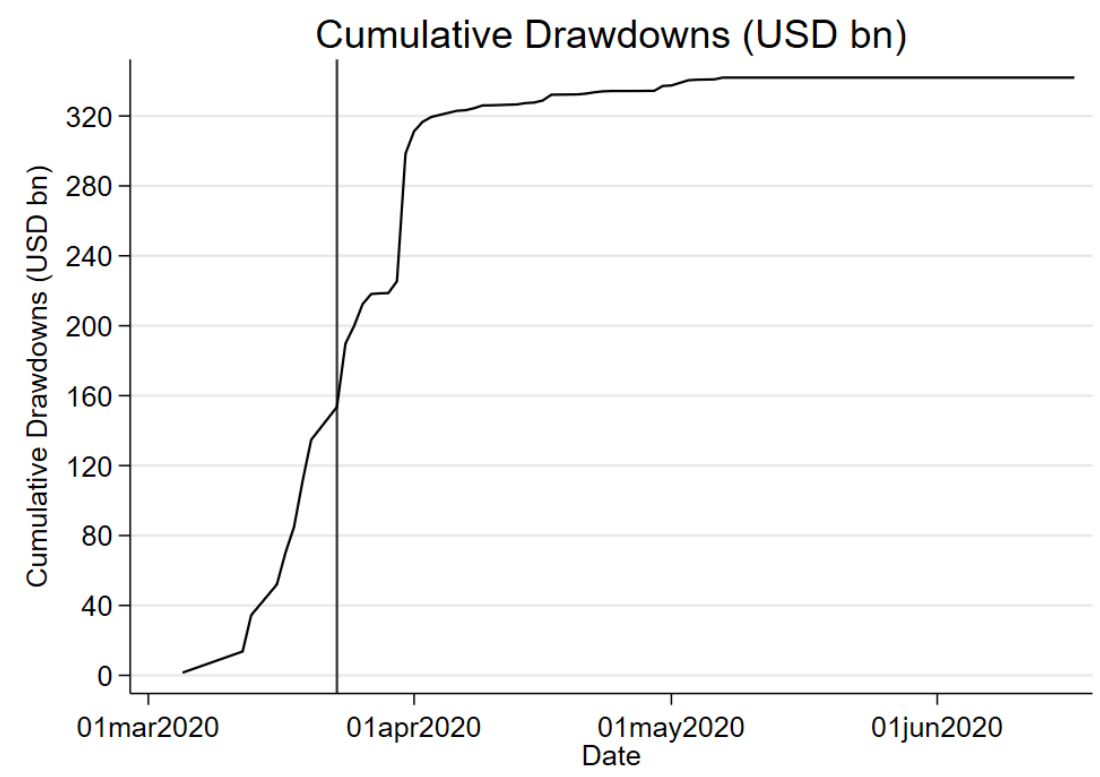

(B) Monthly drawdowns by rating class (in billions of U.S. dollars)

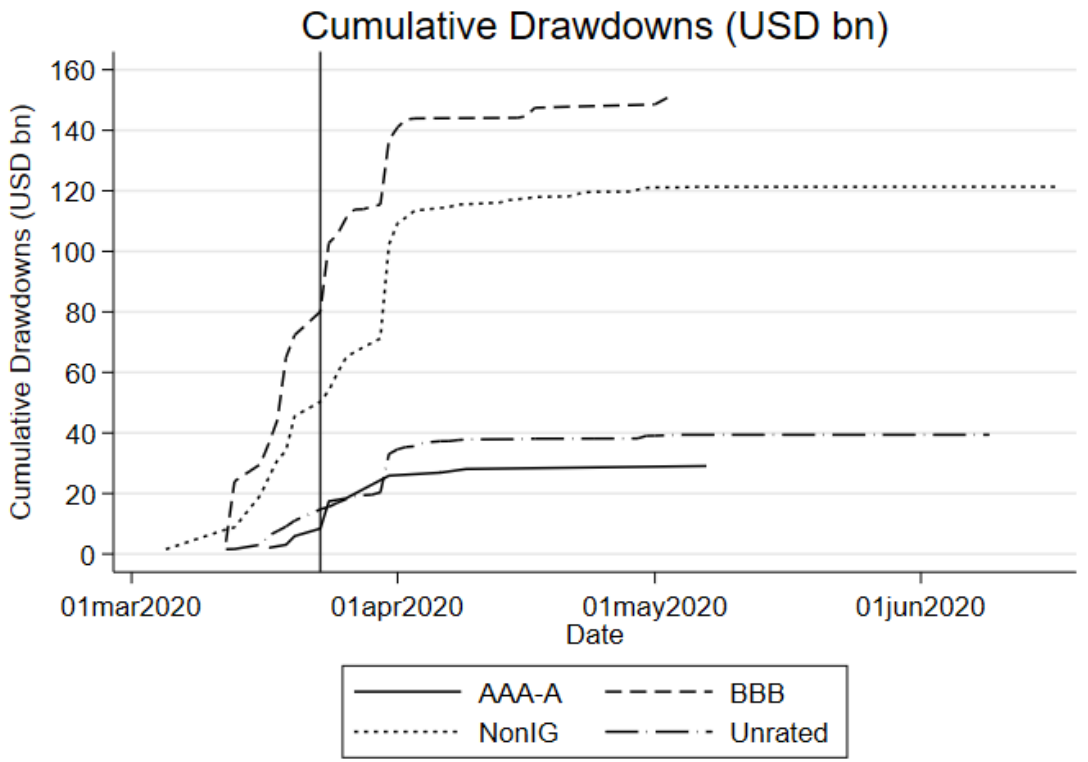


Figure 3. Cumulative drawdowns and drawdown percentage rate

Figure 3 plots the daily credit line drawdowns of U.S. nonfinancial firms as a percentage of the credit line limit for the full sample of firms (panel A) and by rating class (panel B).

\section{(A) Full sample}

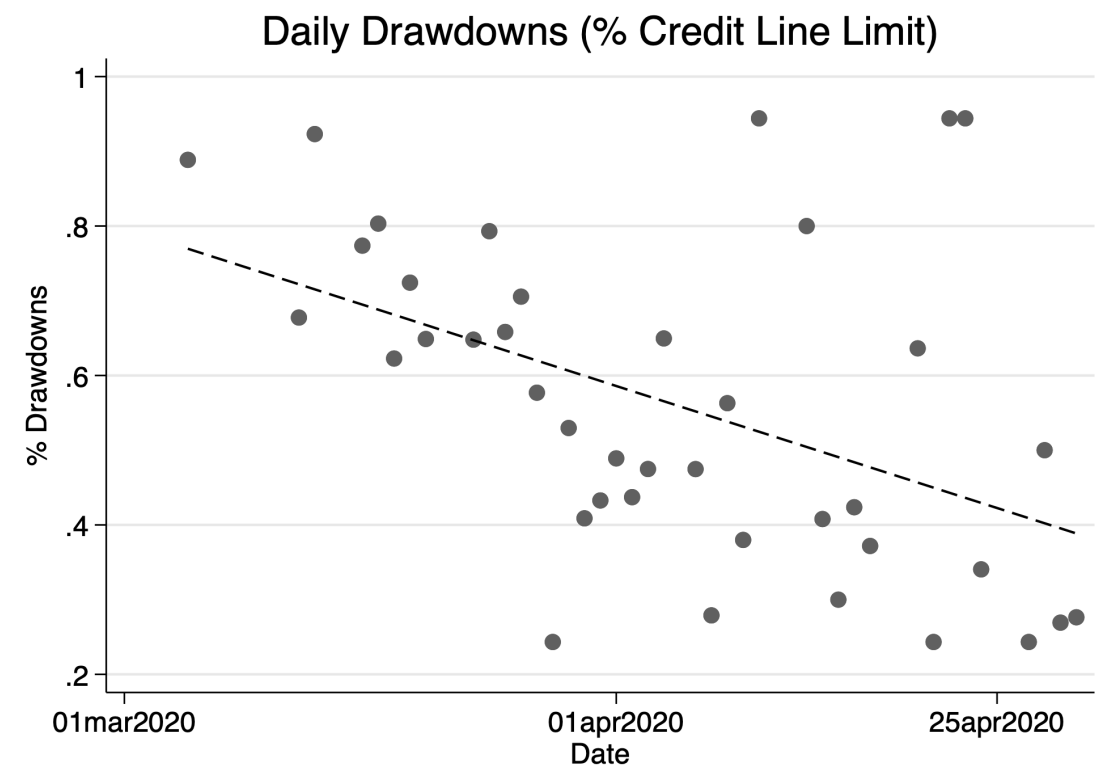

(B) By rating category

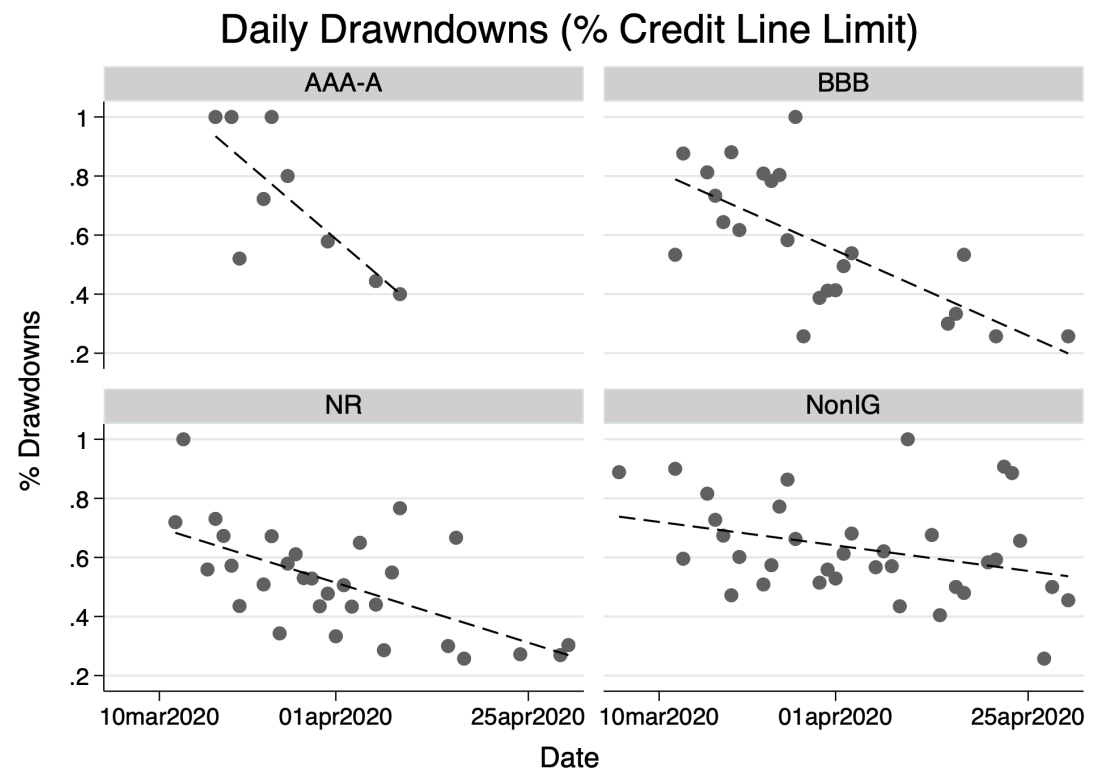


Figure 4. Cumulative drawdowns and drawdown percentage rate

Figure 4 plots the daily credit line drawdowns of U.S. nonfinancial firms as a percentage of the credit line limit (left-hand scale) together with their z-score (right-hand scale) for the full sample of firms (panel A) and by rating class (panel B). The vertical line represents the Fed's announcement of the corporate bond buying program on March 23, 2020.

\section{(A) Full sample}

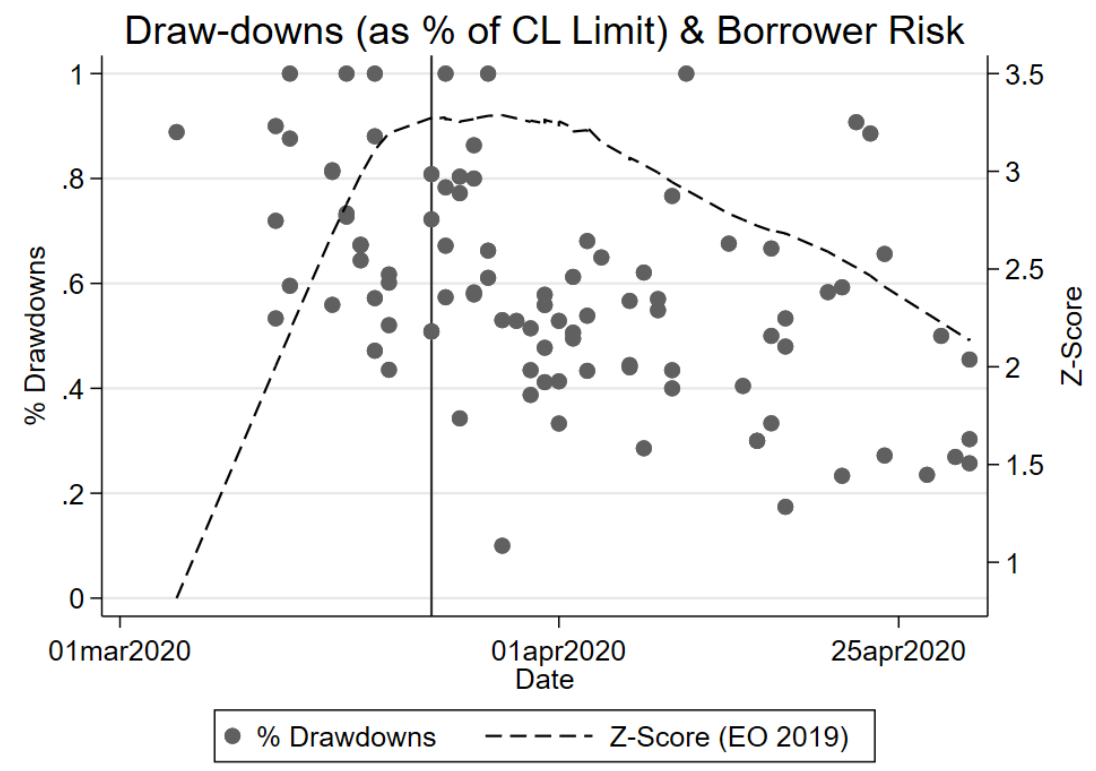

(B) By rating category

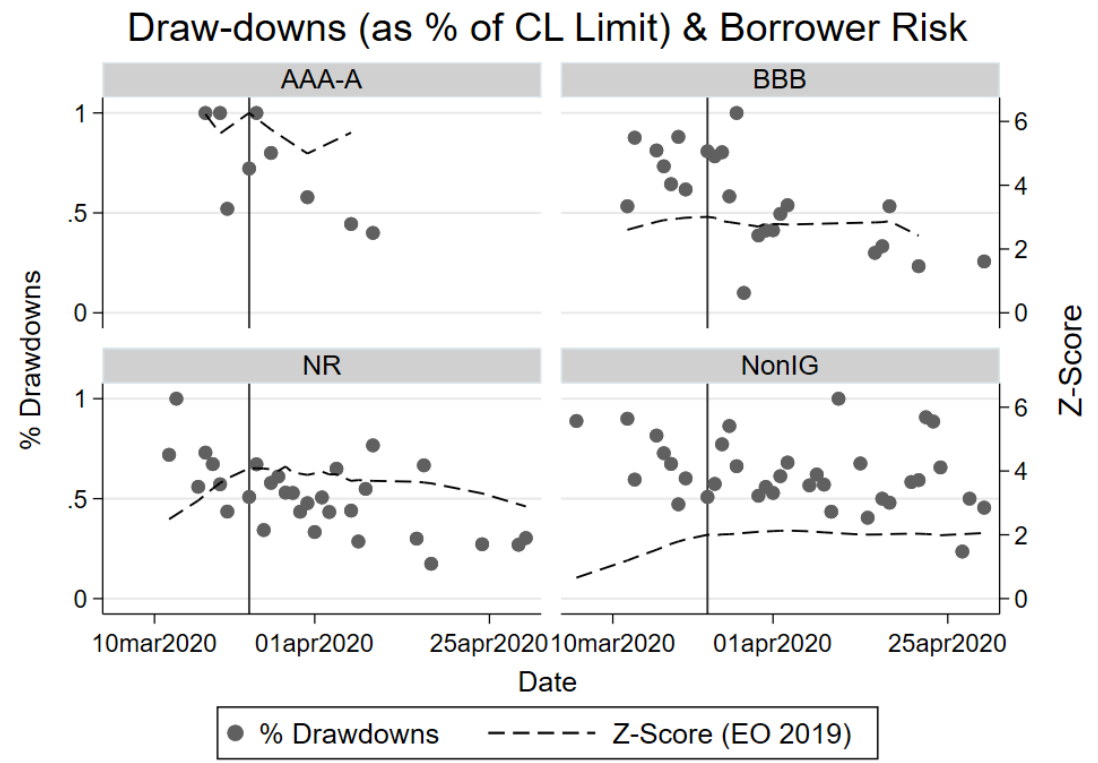




\section{Figure 5. Cumulative bond issuances by U.S. nonfinancial firms}

Figure 5 plots cumulative bond issuances (in billions of U.S. dollars) of U.S. nonfinancial firms over the January 1 to April 9, 2020, period and the average yield-to-maturity of bond issuers for the full sample (panel A) and by rating class (panel B). Panel C plots the yield-to-maturity of bond issues by rating class. Panel D plots the time series of loan and stock returns and credit line drawdowns over the January 1 to April 9, 2020, period. The vertical line represents the Fed's announcement of the corporate bond buying program on March 23, 2020.

\section{(A) Full sample}

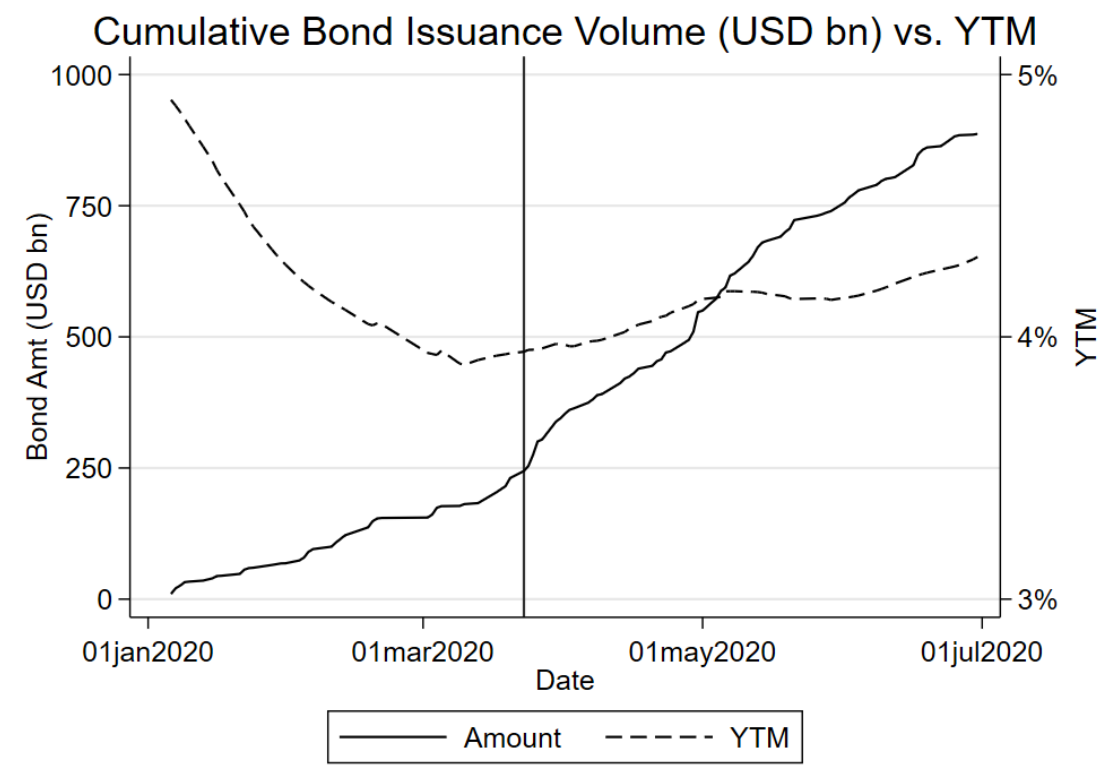

(B) By rating category

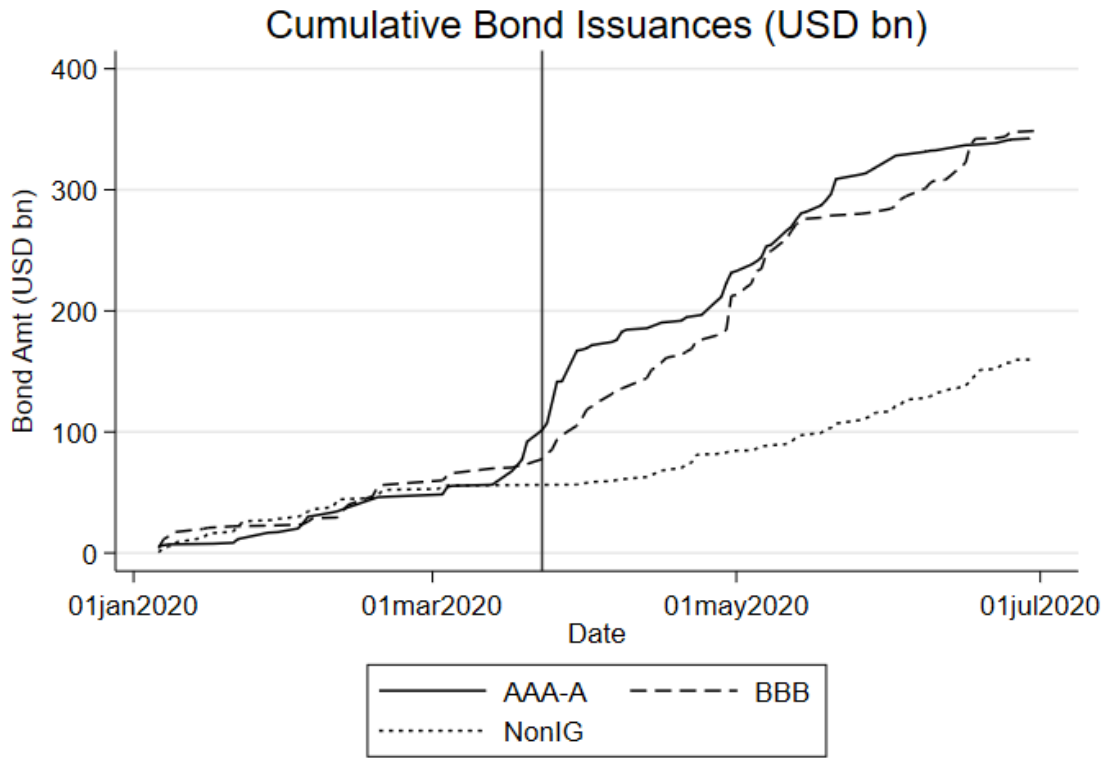


(C) Difference in yield-to-maturity between rating categories

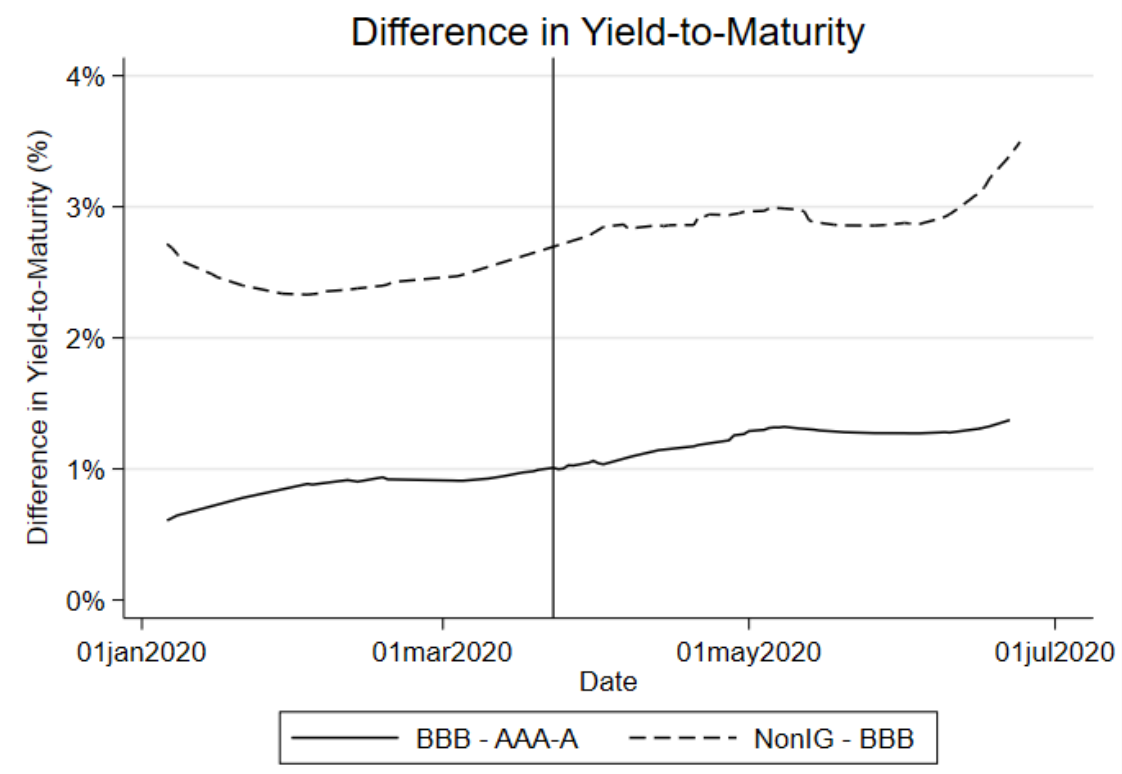

(D) Loan, stock returns, and drawdowns

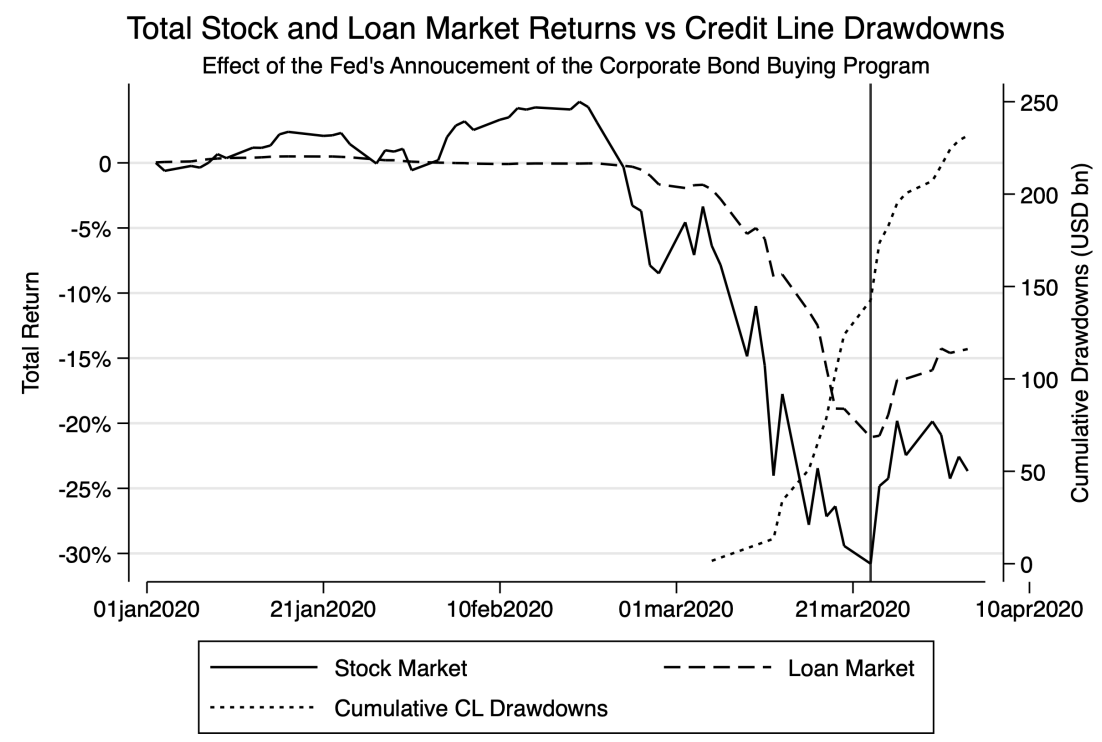

Vertical line indicates the Fed's announcement of the corporate bond buying program. 
Figure 6. Stock price performance by rating class

Figure 6 plots the stock price performance of U.S. nonfinancial firms by rating class (panel A) and by "fallen angels" versus BBB-rated firms (panel B).

\section{(A) By rating category}

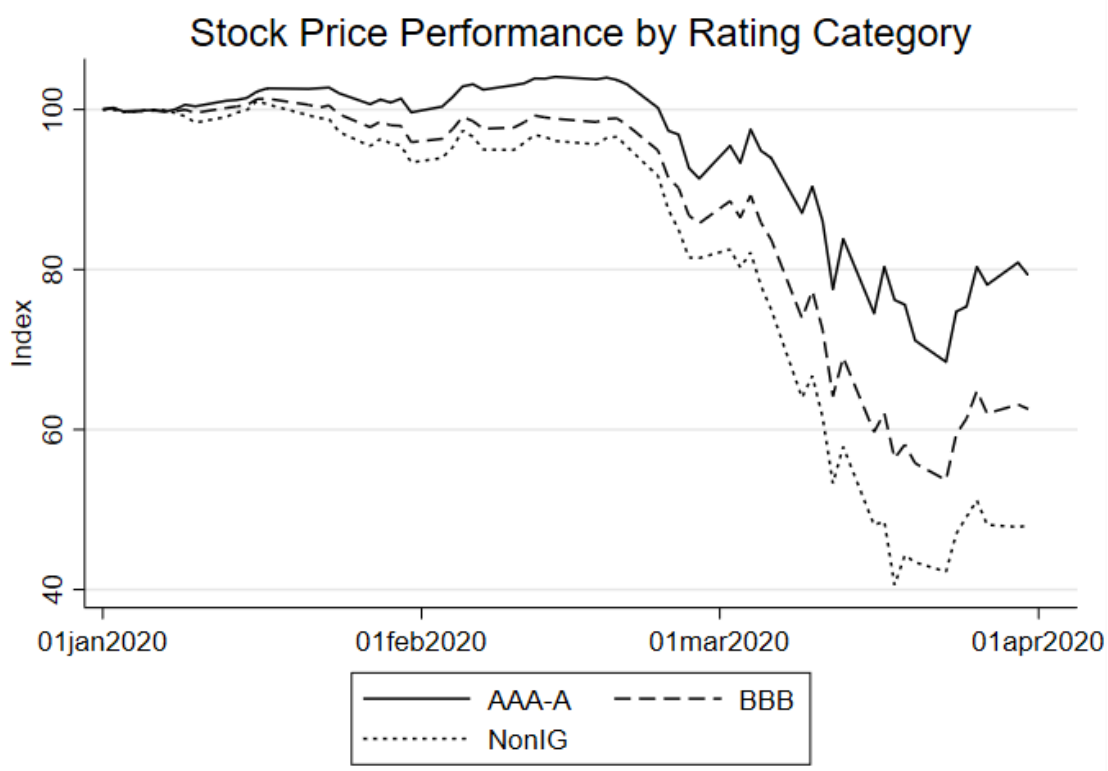

(B) Fallen angels versus BBB

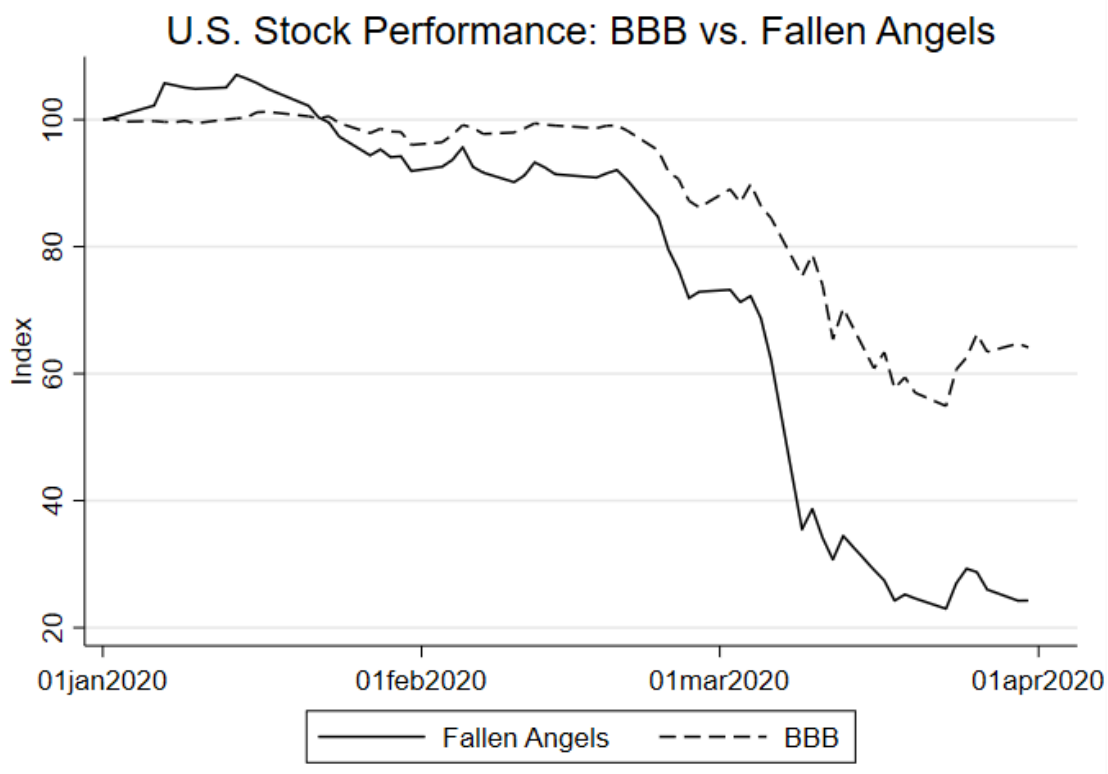




\section{Figure 7. Time series of balance sheet liquidity of U.S. nonfinancial firms}

Figure 7 shows the time series of (median) balance sheet liquidity of U.S. nonfinancial firms over the Q1 2018 to Q1 2020 period as well as of its components (undrawn credit lines-to-assets, cash-to-assets, and short-term-debtto-assets). Panel B shows the differential stock price development of firms with high versus low liquidity risk. The vertical line represents the Fed's announcement of the corporate bond buying program on 23 March 2020.

\section{(A) Firm liquidity (components)}

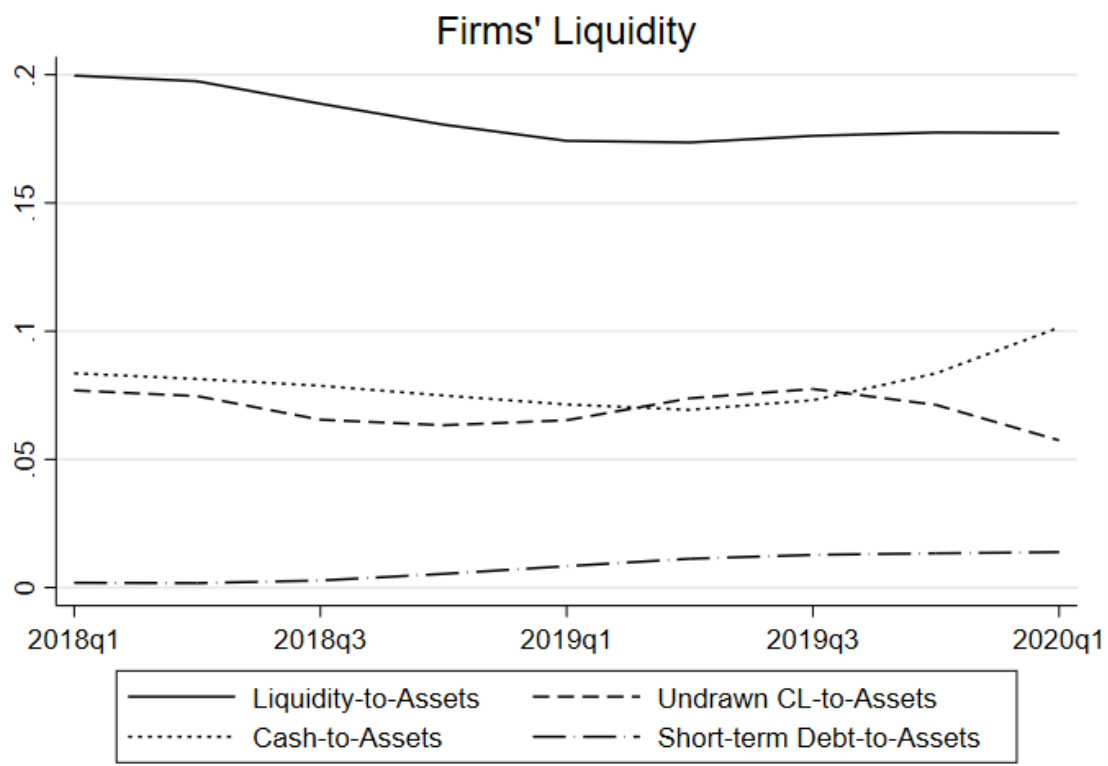

(B) Stock price difference between low liquidity and high liquidity firms

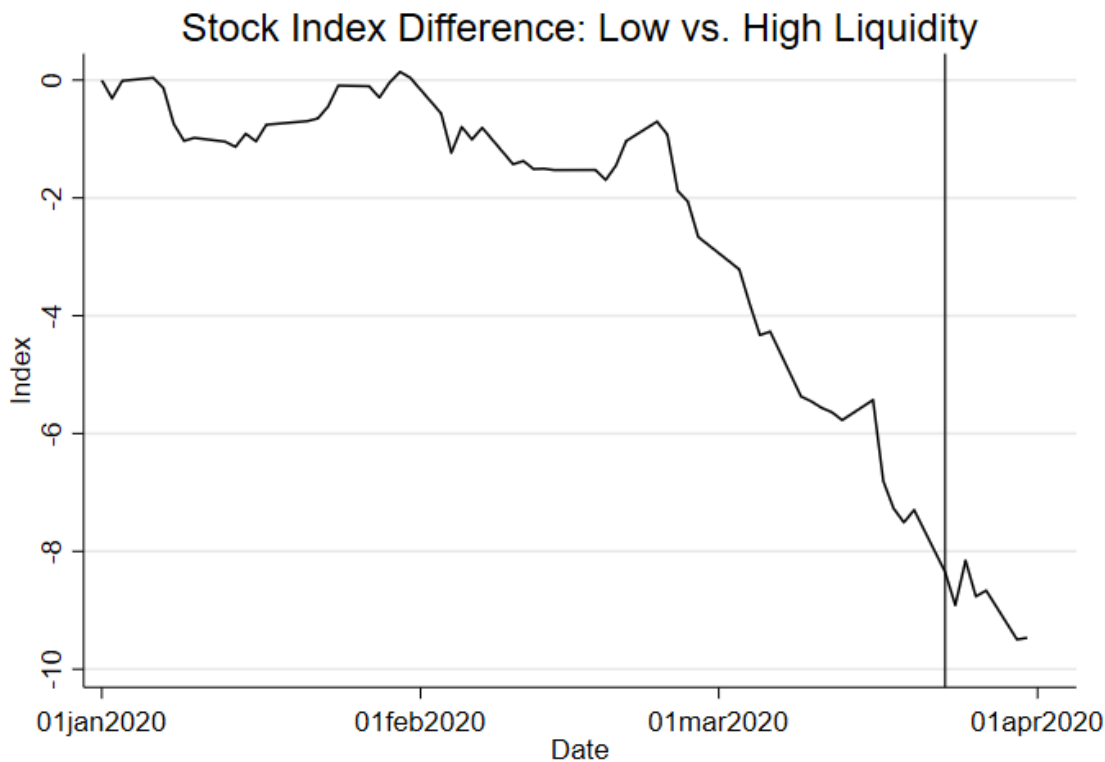


Figure 8. Stock price performance by liquidity, 2007-2009

Figure 8 shows the stock price performance of U.S. nonfinancial firms with high versus low balance sheet liquidity over the 2007 to 2009 period (panel A) and the stock price difference between both groups of firms (panel B).

\section{(A) Performance}

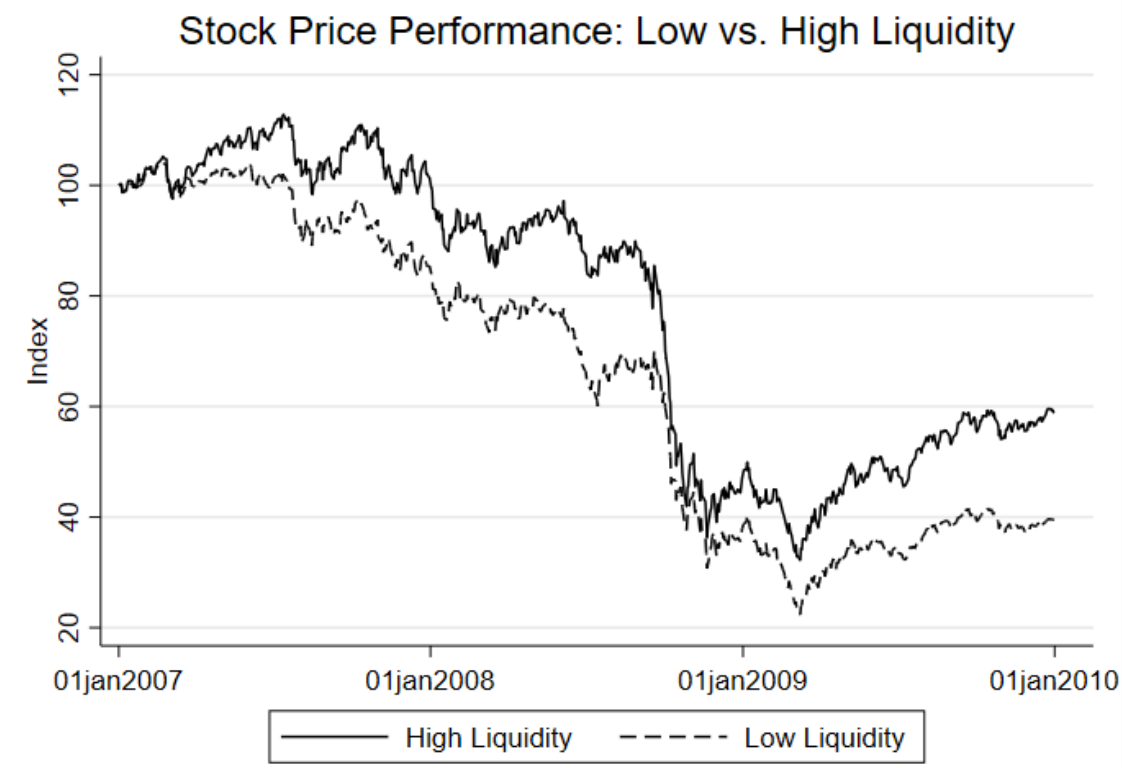

(B) Difference in performance

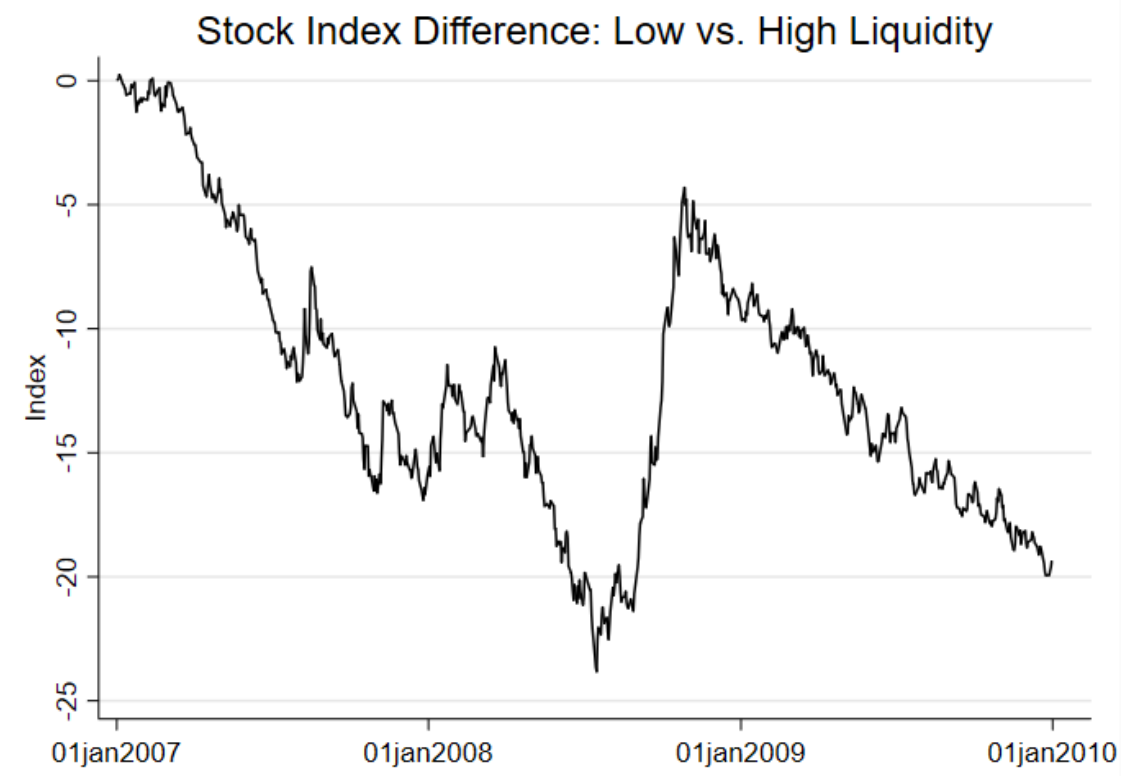


Table 1. Descriptive statistics

Table 1 shows descriptive statistics of 1,803 U.S. nonfinancial firms over the Q1 2018 to Q1 2020 period. Table A1 in the appendix defines all variables.

\begin{tabular}{|c|c|c|c|c|c|c|}
\hline \multirow[b]{2}{*}{ Dependent variables } & $\mathrm{N}$ & Mean & SD & p5 & $\mathrm{p} 50$ & p95 \\
\hline & & & & & & \\
\hline$\Delta \log ($ Cash-to-assets $)$ & 13,646 & 0.02 & 0.64 & -0.79 & 0.00 & 0.97 \\
\hline Cash / (Cash + Undrawn CL) & 13,646 & 0.54 & 0.35 & 0.03 & 0.50 & 1.00 \\
\hline \multicolumn{7}{|l|}{ Independent variables } \\
\hline $\log$ (Total Assets) & 13,646 & 7.53 & 1.70 & 5.00 & 7.41 & 10.61 \\
\hline $\log ($ Cash $)$ & 13,646 & 4.77 & 2.02 & 1.46 & 4.83 & 7.96 \\
\hline Leverage & 13,646 & 0.31 & 0.22 & 0.00 & 0.30 & 0.73 \\
\hline Book-to-market ratio & 13,646 & 0.52 & 0.75 & -0.04 & 0.36 & 1.54 \\
\hline CapEx-to-assets & 13,646 & 0.04 & 0.05 & 0.00 & 0.03 & 0.14 \\
\hline R\&D-to-sales & 13,646 & 0.24 & 1.01 & 0.00 & 0.00 & 0.66 \\
\hline Dividend dummy & 13,646 & 0.48 & 0.50 & 0.00 & 0.00 & 1.00 \\
\hline Loss dummy & 13,646 & 0.30 & 0.46 & 0.00 & 0.00 & 1.00 \\
\hline Beta (36 months) & 12,954 & 1.17 & 0.80 & 0.04 & 1.11 & 2.57 \\
\hline \multicolumn{7}{|l|}{ Rating indicators } \\
\hline Rated & 13,646 & 0.44 & 0.50 & 0.00 & 0.00 & 1.00 \\
\hline NonIG rating & 13,646 & 0.25 & 0.43 & 0.00 & 0.00 & 1.00 \\
\hline IG rating & 13,646 & 0.19 & 0.39 & 0.00 & 0.00 & 1.00 \\
\hline AAA-A rating & 13,646 & 0.06 & 0.23 & 0.00 & 0.00 & 1.00 \\
\hline $\mathrm{BBB}$ rating & 13,646 & 0.13 & 0.34 & 0.00 & 0.00 & 1.00 \\
\hline
\end{tabular}




\section{Table 2. Cash holdings}

Table 2 shows the results of OLS regressions of $\Delta \log$ (Cash-to-assets) on quarter dummies, quarter dummies interacted with rating classes, and control variables, including Leverage, Book-to-market ratio, CapEx-to-assets, $R \& D$-to-sales, and a Dividend and a Loss dummy. Control variables remain unreported for brevity. In addition, we control for the respective rating category in columns 1 to 3 and add Beta as an additional control in columns 4 to 6. All regressions include firm fixed effects. Standard errors are clustered at the firm level. We report $p$-values based on standard errors clustered at the firm level in parentheses. Table A1 in the appendix defines all variables. $* p<.1 ; * * p<.05 ; * * * p<.01$.

\begin{tabular}{|c|c|c|c|c|c|c|}
\hline & \multicolumn{3}{|c|}{$\Delta \log ($ Cash-to-assets $)$} & \multicolumn{3}{|c|}{ Cash / (Cash + Undrawn CL) } \\
\hline & (1) & (2) & (3) & (4) & (5) & (6) \\
\hline Q1 $2020 \times$ Rated & $\begin{array}{c}0.2016^{* * *} \\
(0.000)\end{array}$ & & & $\begin{array}{c}0.0381 * * * \\
(0.000)\end{array}$ & & \\
\hline Q1 2020 x IG rating & & $\begin{array}{c}0.1902 * * * \\
(0.000)\end{array}$ & & & $\begin{array}{l}0.0003 \\
(0.981)\end{array}$ & \\
\hline Q1 2020 x NonIG rating & & $\begin{array}{c}0.2101 * * * \\
(0.000)\end{array}$ & $\begin{array}{c}0.2101 * * * \\
(0.000)\end{array}$ & & $\begin{array}{c}0.0671^{* * *} \\
(0.000)\end{array}$ & $\begin{array}{c}0.0671^{* * *} \\
(0.000)\end{array}$ \\
\hline Q1 $2020 \times$ AAA-A rating & & & $\begin{array}{l}0.0913 \\
(0.293)\end{array}$ & & & $\begin{array}{c}-0.0111 \\
(0.575)\end{array}$ \\
\hline Q1 2020 x BBB rating & & & $\begin{array}{c}0.2336^{* * *} \\
(0.000)\end{array}$ & & & $\begin{array}{l}0.0053 \\
(0.710)\end{array}$ \\
\hline Q1 2020 & $\begin{array}{c}0.2523 * * * \\
(0.000)\end{array}$ & $\begin{array}{c}0.2523 * * * \\
(0.000)\end{array}$ & $\begin{array}{c}0.2524 * * * \\
(0.000)\end{array}$ & $\begin{array}{c}0.0630^{* * *} \\
(0.000)\end{array}$ & $\begin{array}{c}0.0630^{* * *} \\
(0.000)\end{array}$ & $\begin{array}{c}0.0630^{* * * *} \\
(0.000)\end{array}$ \\
\hline Q4 2019 & $\begin{array}{c}0.0607 * * * \\
(0.002)\end{array}$ & $\begin{array}{c}0.0607 * * * \\
(0.002)\end{array}$ & $\begin{array}{c}0.0607 * * * \\
(0.002)\end{array}$ & $\begin{array}{c}-0.0316^{* * *} \\
(0.000)\end{array}$ & $\begin{array}{c}-0.0314 * * * \\
(0.000)\end{array}$ & $\begin{array}{c}-0.0314 * * * \\
(0.000)\end{array}$ \\
\hline Q3 2019 & $\begin{array}{c}0.0486 * * * \\
(0.006)\end{array}$ & $\begin{array}{c}0.0486^{* * *} \\
(0.006)\end{array}$ & $\begin{array}{c}0.0486 * * * \\
(0.006)\end{array}$ & $\begin{array}{c}-0.0331 * * * \\
(0.000)\end{array}$ & $\begin{array}{c}-0.0330 * * * \\
(0.000)\end{array}$ & $\begin{array}{c}-0.0330 * * * \\
(0.000)\end{array}$ \\
\hline Q2 2019 & $\begin{array}{l}0.0280 \\
(0.134)\end{array}$ & $\begin{array}{l}0.0280 \\
(0.134)\end{array}$ & $\begin{array}{l}0.0280 \\
(0.134)\end{array}$ & $\begin{array}{c}-0.0334 * * * \\
(0.000)\end{array}$ & $\begin{array}{c}-0.0334 * * * \\
(0.000)\end{array}$ & $\begin{array}{c}-0.0334 * * * \\
(0.000)\end{array}$ \\
\hline Q1 2019 & $\begin{array}{c}-0.1374 * * * \\
(0.000)\end{array}$ & $\begin{array}{c}-0.1374 * * * \\
(0.000)\end{array}$ & $\begin{array}{c}-0.1373 * * * \\
(0.000)\end{array}$ & $\begin{array}{c}-0.0152 * * * \\
(0.004)\end{array}$ & $\begin{array}{c}-0.0152 * * * \\
(0.004)\end{array}$ & $\begin{array}{c}-0.0151 * * * \\
(0.004)\end{array}$ \\
\hline Q4 2018 & $\begin{array}{l}0.0250 \\
(0.199)\end{array}$ & $\begin{array}{l}0.0250 \\
(0.199)\end{array}$ & $\begin{array}{l}0.0251 \\
(0.198)\end{array}$ & $\begin{array}{c}0.1464 * * * \\
(0.000)\end{array}$ & $\begin{array}{c}0.1463 * * * \\
(0.000)\end{array}$ & $\begin{array}{c}0.1463 * * * \\
(0.000)\end{array}$ \\
\hline Q3 2018 & $\begin{array}{l}0.0091 \\
(0.632)\end{array}$ & $\begin{array}{l}0.0091 \\
(0.632)\end{array}$ & $\begin{array}{l}0.0091 \\
(0.630)\end{array}$ & $\begin{array}{c}0.0095^{*} \\
(0.063)\end{array}$ & $\begin{array}{c}0.0094 * \\
(0.064)\end{array}$ & $\begin{array}{c}0.0094 * \\
(0.064)\end{array}$ \\
\hline $\begin{array}{l}\text { Controls } \\
\text { Firm FE }\end{array}$ & Yes & Yes & Yes & Yes & Yes & $\begin{array}{l}\text { Yes } \\
\text { Yes }\end{array}$ \\
\hline $\begin{array}{l}\text { Firm FE } \\
R^{2}\end{array}$ & .1117 & .1117 & .1121 & $\begin{array}{c}\text { Yes } \\
.1282\end{array}$ & $\begin{array}{l}\text { Yes } \\
.1300\end{array}$ & $\begin{array}{l}\text { Yes } \\
.1300\end{array}$ \\
\hline Number obs. & 13,646 & 13,646 & 13,646 & 12,954 & 12,954 & 12,954 \\
\hline
\end{tabular}




\section{Table 3. Raising cash (quarterly balance sheet data)}

In this table, we focus on how firms raised cash during Q1 2020. Panel A reports the results of differences-inmean tests of debt structure components of U.S. firms, for the full sample, and for each rating category individually, including Drawn CL / Assets, Drawn CL / (Drawn CL + Undrawn CL), Bond Debt / Assets, Term Loans / Assets, and Total Debt / Assets and Cash / (Cash + Undrawn CL). Panel B reports the results of crosssectional regressions analyzing the debt structure differences among firms across rating classes in Q1 2020. The dependent variables are Drawn CL / Assets (column 1), Bond Debt / Assets (column 2), Term Loans / Assets (column 3). The dependent variables are Equity Issuances/Assets (column 4) and Payouts /Assets (column 5). Panel $\mathrm{C}$ reports the results of cross-sectional regressions analyzing changes in debt structure components from Q4 2019 to Q1 2019 across rating classes. The dependent variables are $\triangle$ Drawn $C L_{\text {/ Asset }}$-1 (column 1), $\Delta$ Credit Line Usage (column 2), $\Delta$ Bond Debt / Assett-1 (column 3), and $\Delta$ Term Loans / Asset t-1 (column 4). We include in all regressions a set of firm characteristics that determine a firm's demand for debt: $\log ($ Assets), EBITDA/Assets, Tangible Assets/Assets, Leverage, Current Ratio, and the MTB ratio and industry fixed effects (two-digit SIC codes). All control variables enter our regression with a one-quarter lag. Table A1 in the appendix defines all variables. We report robust standard errors in parentheses. ${ }^{*} p<.1 ; * * p<.05 ; * * * p<.01$.

\section{A. Differences-in-mean tests}

Full sample $(\mathrm{N}=1,971)$

\begin{tabular}{|c|c|c|c|c|}
\hline & Q4 2019 & Q1 2020 & $t$-test (diff) & $p$-value \\
\hline Drawn CL/assets & 0.035 & 0.054 & 0.019 & $<.001 * * *$ \\
\hline Drawn CL/(Drawn CL + Undrawn CL) & 0.192 & 0.374 & 0.182 & $<.001 * * *$ \\
\hline Bond debt/assets & 0.144 & 0.145 & 0.001 & .422 \\
\hline Term loans/assets & 0.083 & 0.082 & -0.001 & .175 \\
\hline Total debt/assets & 0.334 & 0.358 & 0.024 & $<.001 * * *$ \\
\hline Cash/(Cash + Undrawn CL) & 0.525 & 0.629 & 0.105 & $<.001 * * *$ \\
\hline \multicolumn{5}{|l|}{ AAAA-A rating } \\
\hline & Q4 2019 & Q1 2020 & $t$-test (diff) & $p$-value \\
\hline Drawn CL/assets & 0.003 & 0.012 & 0.009 & $<.001 * * *$ \\
\hline Drawn CL/(Drawn CL + Undrawn CL) & 0.033 & 0.141 & 0.109 & $<.001 * * *$ \\
\hline Bond debt/assets & 0.291 & 0.301 & 0.010 & .11 \\
\hline Term loans/assets & 0.007 & 0.008 & 0.001 & .612 \\
\hline Total debt/assets & 0.341 & 0.351 & 0.010 & $.07 *$ \\
\hline Cash/(Cash + Undrawn CL) & 0.484 & 0.574 & 0.090 & $<.001 * * *$ \\
\hline \multicolumn{5}{|l|}{ BBB rating } \\
\hline & Q4 2019 & Q1 2020 & $t$-test (diff) & $p$-value \\
\hline Drawn CL/assets & 0.011 & 0.030 & 0.019 & $<.001 * * *$ \\
\hline Drawn CL/(Drawn CL + Undrawn CL) & 0.070 & 0.235 & 0.165 & $<.001 * * *$ \\
\hline Bond debt/assets & 0.277 & 0.282 & 0.005 & $.02 * *$ \\
\hline Term loans/assets & 0.017 & 0.022 & 0.005 & $<.001 * * *$ \\
\hline Total debt/assets & 0.360 & 0.378 & 0.018 & $<.001 * * *$ \\
\hline Cash/(Cash + Undrawn CL) & 0.333 & 0.438 & 0.106 & $<.001 * * *$ \\
\hline \multicolumn{5}{|l|}{ NonIG rating } \\
\hline & Q4 2019 & Q1 2020 & $t$-test (diff) & $p$-value \\
\hline Drawn CL/assets & 0.034 & 0.065 & 0.032 & $<.001 * * *$ \\
\hline Drawn CL/(Drawn CL + Undrawn CL) & 0.161 & 0.426 & 0.265 & $<.001 * * *$ \\
\hline Bond debt/assets & 0.225 & 0.225 & 0.000 & .95 \\
\hline Term loans/assets & 0.156 & 0.152 & -0.004 & $.04 * *$ \\
\hline Total debt/assets & 0.484 & 0.520 & 0.036 & $<.001 * * *$ \\
\hline Cash/(Cash + Undrawn CL) & 0.365 & 0.534 & 0.168 & $<.001 * * *$ \\
\hline \multicolumn{5}{|l|}{ Unrated } \\
\hline & Q4 2019 & Q1 2020 & $t$-test (diff) & $p$-value \\
\hline Drawn CL/assets & 0.043 & 0.056 & 0.014 & $<.001 * * *$ \\
\hline Drawn CL/(Drawn CL + Undrawn CL) & 0.260 & 0.407 & 0.147 & $<.001 * * *$ \\
\hline Bond debt/assets & 0.074 & 0.075 & 0.001 & .97 \\
\hline Term loans/assets & 0.073 & 0.071 & -0.002 & .3 \\
\hline Total debt/assets & 0.269 & 0.291 & 0.022 & $<.001 * * *$ \\
\hline Cash/(Cash + Undrawn CL) & 0.626 & 0.707 & 0.080 & $<.001 * * *$ \\
\hline
\end{tabular}




\begin{tabular}{|c|c|c|c|c|c|}
\hline & $\begin{array}{c}\text { (1) } \\
\text { Q1 2020: Drawn } \\
\text { CL/assets } \\
\end{array}$ & $\begin{array}{c}\text { (2) } \\
\text { Q1 2020: Bond } \\
\text { debt/assets }\end{array}$ & $\begin{array}{c}\text { (3) } \\
\text { Q1 2020: Term } \\
\text { loans/assets }\end{array}$ & $\begin{array}{c}\text { (4) } \\
\text { Q1 2020: Equity } \\
\text { issuances/assets }\end{array}$ & $\begin{array}{c}\text { (5) } \\
\text { Q1 2020: } \\
\text { Payouts/assets } \\
\end{array}$ \\
\hline AAA-A & $\begin{array}{c}-0.049 * * * \\
(0.007)\end{array}$ & $\begin{array}{c}0.088^{* * *} \\
(0.014)\end{array}$ & $\begin{array}{c}-0.039 * * * \\
(0.010)\end{array}$ & $\begin{array}{l}0.007 * \\
(0.003)\end{array}$ & $\begin{array}{c}0.006 * * * \\
(0.001)\end{array}$ \\
\hline BBB & $\begin{array}{c}-0.042 * * * \\
(0.006)\end{array}$ & $\begin{array}{c}0.093 * * * \\
(0.010)\end{array}$ & $\begin{array}{c}-0.038 * * * \\
(0.008)\end{array}$ & $\begin{array}{c}0.002 \\
(0.002)\end{array}$ & $\begin{array}{c}0.003 * * * \\
(0.000)\end{array}$ \\
\hline NonIG & $\begin{array}{c}-0.026^{* * *} \\
(0.006)\end{array}$ & $\begin{array}{c}0.027^{* *} \\
(0.011)\end{array}$ & $\begin{array}{c}0.036^{* * * *} \\
(0.009)\end{array}$ & $\begin{array}{l}-0.001 \\
(0.002)\end{array}$ & $\begin{array}{c}0.000 \\
(0.000)\end{array}$ \\
\hline $\begin{array}{l}\text { Controls } \\
R^{2} \\
\text { Number obs. }\end{array}$ & $\begin{array}{c}\text { Yes } \\
.270 \\
1,971\end{array}$ & $\begin{array}{c}\text { Yes } \\
.522 \\
1,971\end{array}$ & $\begin{array}{c}\text { Yes } \\
.347 \\
1,971\end{array}$ & $\begin{array}{c}\text { Yes } \\
.194 \\
1,960\end{array}$ & $\begin{array}{l}\text { Yes } \\
.264 \\
1,960\end{array}$ \\
\hline $\begin{array}{l}\mathrm{AAA}-\mathrm{A}=\mathrm{BBB} \\
\mathrm{BBB}=\text { NonIG }\end{array}$ & $\begin{array}{c}0.0948 * \\
0.003 * * *\end{array}$ & $\begin{array}{c}0.615 \\
<0.001 * * *\end{array}$ & $\begin{array}{c}0.877 \\
<0.001 * * *\end{array}$ & $\begin{array}{c}0.003 * * * \\
0.050 *\end{array}$ & $\begin{array}{l}<0.001 * * * \\
<0.001 * * *\end{array}$ \\
\hline
\end{tabular}

\section{Regression results (changes in Q4 2019-Q1 2020)}

\begin{tabular}{lcccc}
\hline & $(1)$ & $(2)$ & $(3)$ & $(4)$ \\
& $\Delta$ Drawn CL/asset $_{\mathrm{t}-1}$ & $\Delta$ Credit line usage & $\Delta$ Bond debt/Asset $_{\mathrm{t}-1}$ & $\Delta$ Term loans/Asset $_{\mathrm{t}-1}$ \\
\hline AAA-A & $-0.009^{*}$ & -0.047 & $0.015^{* *}$ & -0.004 \\
& $(0.005)$ & $(0.039)$ & $(0.006)$ & $(0.003)$ \\
BBB & 0.001 & 0.009 & 0.002 & 0.002 \\
& $(0.004)$ & $(0.003)$ & $(0.003)$ & $(0.002)$ \\
NonIG & $0.011^{* * *}$ & $0.085^{* * *}$ & -0.004 & 0.000 \\
& $(0.003)$ & $(0.022)$ & $(0.002)$ & $(0.002)$ \\
Controls & Yes & Yes & Yes & .0509 \\
$R^{2}$ & .155 & .179 & .0573 & 1,971 \\
Number obs. & 1,971 & 1,512 & 1,971 & $0.005^{* * *}$ \\
AAA-A = BBB & $0.004^{* * *}$ & $0.092^{*}$ & $0.009^{* * *}$ & 0.5122 \\
BBB = NonIG & $0.004^{* * *}$ & $0.005^{* * *}$ & $0.060^{*}$ & \\
\hline
\end{tabular}




\section{Table 4. Stress test and drawdowns in March}

This table reports a comparison of credit line usage of U.S. firms in March and April 2020 with credit line usage rates at the end of 2008. Undrawn CL are the undrawn credit lines of firms at the end of 2019. Expected Drawdown Rate (2008) is Credit Line / (Credit Line + Undrawn CL) measured at the end of 2008. Expected Drawdowns equals Undrawn CL $x$ Expected Drawdown Rate (2008). Actual Drawdowns are the realized drawdowns at the end of March (March (Drawdowns)) or the end of April (April (Drawdowns)). March (Drawdown Rate) and April (Drawdown Rate) is calculated as the Actual Drawdowns in the particular month divided by Undrawn CL. March \& April (Drawdowns) is the sum of March (Drawdowns) and April (Drawdowns). Amounts are in billions of U.S. dollars.

\begin{tabular}{|c|c|c|c|c|c|c|c|c|c|}
\hline & \multirow[b]{2}{*}{ Undrawn CL } & \multirow{2}{*}{$\begin{array}{c}\text { Expected } 2008 \\
\text { drawdown rate } \\
(\%)\end{array}$} & \multirow[b]{2}{*}{$\begin{array}{l}\text { Expected } \\
\text { drawdowns }\end{array}$} & \multicolumn{6}{|c|}{ Actual drawdowns } \\
\hline & & & & $\begin{array}{c}\text { March } \\
\text { drawdowns }\end{array}$ & $\begin{array}{l}\text { March drawdown } \\
\text { rate }(\%)\end{array}$ & April drawdowns & $\begin{array}{l}\text { April drawdown } \\
\text { rate }(\%)\end{array}$ & $\begin{array}{l}\text { March \& April } \\
\text { drawdowns }\end{array}$ & $\begin{array}{l}\text { March \& April } \\
\text { drawdown rate } \\
(\%)\end{array}$ \\
\hline AAA-A & 322,183 & 17.00 & 54,771 & 25,872 & 8.03 & 2,200 & 0.74 & 28,072 & 8.71 \\
\hline BBB & 449,817 & 23.80 & 107,056 & 136,766 & 30.40 & 11,684 & 3.73 & 148,450 & 33.00 \\
\hline NonIG & 309,163 & 28.50 & 88,111 & 102,256 & 33.08 & 18,744 & 9.06 & 121,000 & 39.14 \\
\hline Unrated & 162,725 & 39.20 & 63,788 & 33,034 & 20.30 & 6,012 & 4.64 & 39,047 & 24.00 \\
\hline Total & $1,243,888$ & & 313,726 & 297,928 & & 38,640 & & 336,568 & \\
\hline
\end{tabular}




\section{Table 5. Dash for cash by fallen angels}

Panel A of Table 5 reports the realized stock returns of BBB and BB-rated firms. The matched sample results are based on a propensity score matching process. We calculate the propensity score using a logit model where the dependent variable is an indicator that is one if the firm has a BBB rating and zero if it has a BB rating. The regressor is the $\mathrm{z}$-score. Panel $\mathrm{B}$ reports results from a cross-sectional regression analyzing the drawdown behavior of U.S. nonfinancial firms as a function of their respective risk. AAA-A, BBB, and nonIG are the rating categories (unrated is the omitted group). In column 1, we use the $\mathrm{z}$-score and interaction of rating indicators with the $z$-score in the full sample as risk measure. Column 2 shows the results of the unmatched sample of BBB-rated and BBrated firms. The results in column 3 were obtained from a matched sample using propensity score (PS) matching. We calculate the propensity score using logit models where the dependent variable is an indicator that is one if the firm has a BBB rating and zero if it has a BB rating. The regressor is the z-score. We also include industry fixed effects in the logit models. We use frequency weights (based on the number of observations from the treated group for which the control group observation is a match) in the matched-sample regression. In column 4, we also match on other differential covariates for being BBB- or BB-rated or the outcome variable: $\log$ (Market Assets), MTB, Debt/EBITDA, Undrawn CL, Debt/Assets, Current Ratio, and Tangible Assets / Assets, all measured at the end of 2019. $t$-statistics are in parentheses. Table A1 in the appendix defines all variables. ${ }^{*} p<.1 ; * * p<.05 ; * * * p<.01$.

\begin{tabular}{llccccc}
\multicolumn{1}{l}{ A. Stock returns } & \multicolumn{1}{c}{} \\
\hline Sample & BBB & BB & Difference & SE & $t$-stat \\
\hline Stock return & $\begin{array}{l}\text { Unmatched } \\
\text { Matched } \\
\text { (z-score) }\end{array}$ & -0.49 & -0.612 & 0.13 & 0.032 & 3.79 \\
\hline
\end{tabular}

\section{B. Drawdowns}

\begin{tabular}{|c|c|c|c|c|}
\hline & \multicolumn{4}{|c|}{ Dependent variable: $\log$ (Total drawdowns) } \\
\hline & $\begin{array}{l}\text { Full sample } \\
\qquad \begin{array}{c}(1) \\
\end{array}\end{array}$ & $\begin{array}{l}\text { Cliff (BBB- } \\
\text { Unmatched } \\
(2)\end{array}$ & $\begin{array}{l}\text { rated firms) } \\
\text { PS matched } \\
\text { (z-score) } \\
(3)\end{array}$ & $\begin{array}{c}\text { PS matched } \\
\text { (z-score+Controls) } \\
(4)\end{array}$ \\
\hline AAA-A x z-score & $\begin{array}{l}0.02 \\
(.46)\end{array}$ & & & \\
\hline BBB x z-score & $\begin{array}{c}-0.277 * * \\
(-2.31)\end{array}$ & & & \\
\hline NonIG x z-score & $\begin{array}{l}0.05 \\
(1.1)\end{array}$ & & & \\
\hline z-score & $\begin{array}{c}0.017 \\
(.3)\end{array}$ & & & \\
\hline AAA-A & $\begin{array}{c}1.23 * * * \\
(4.45)\end{array}$ & & & \\
\hline BBB & $\begin{array}{c}2.111 * * * \\
(5.06)\end{array}$ & $\begin{array}{c}0.926 * * * \\
(5.25)\end{array}$ & $\begin{array}{c}1.216^{* * *} \\
(6.73)\end{array}$ & $\begin{array}{c}0.633 * * * \\
(3.41)\end{array}$ \\
\hline NonIG & $\begin{array}{c}-1.154 * * * \\
(-6.69)\end{array}$ & & & \\
\hline Controls & Yes & & & Yes \\
\hline Industry FE & Yes & Yes & Yes & Yes \\
\hline Frequency weights & & & Yes & Yes \\
\hline $\mathrm{N}$ & 408 & 151 & 114 & 106 \\
\hline$R^{2}$ & $.368 \%$ & $.165 \%$ & $.288 \%$ & $.101 \%$ \\
\hline Treated & & & 57 & 53 \\
\hline Control & & & 57 & 53 \\
\hline
\end{tabular}




\section{Table 6. Descriptive statistics}

This table reports summary statistics for the key variables in our stock return sample. In panel A, we show descriptive statistics of the liquidity measure, that is, Undrawn CL-to-Assets, Cash-to-Assets, and Short-term Debtto-Assets, for different rating classes. Panel B reports other firm characteristics and stock returns. Table A1 in the appendix defines all variables.

\section{A. Liquidity by rating category}

\begin{tabular}{lcccccccc}
\hline & \multicolumn{2}{c}{ AAA-A } & \multicolumn{2}{c}{ BBB } & \multicolumn{2}{c}{ NonIG } & \multicolumn{2}{c}{ Unrated } \\
& $\mathrm{N}$ & Mean & $\mathrm{N}$ & Mean & $\mathrm{N}$ & Mean & $\mathrm{N}$ & Mean \\
\hline Liquidity & 100 & 0.178 & 230 & 0.155 & 470 & 0.160 & 1,051 & 0.297 \\
Undrawn CL-to-assets & 100 & 0.085 & 230 & 0.106 & 470 & 0.113 & 1,051 & 0.091 \\
Cash-to-assets & 100 & 0.120 & 230 & 0.074 & 470 & 0.071 & 1,051 & 0.231 \\
Short-term debt-to-assets & 100 & 0.050 & 230 & 0.035 & 470 & 0.034 & 1,051 & 0.033 \\
\hline
\end{tabular}

\section{B. Firm characteristics (Q4 2019)}

\begin{tabular}{|c|c|c|c|c|c|c|}
\hline & $\mathrm{N}$ & Mean & $\mathrm{SD}$ & p5 & p50 & p95 \\
\hline \multicolumn{7}{|l|}{ Dependent variables } \\
\hline Return January 1-March 23, 2020 & 1,851 & -0.60 & 0.42 & -1.38 & -0.53 & -0.07 \\
\hline Return January 1-January 31, 2020 & 1,851 & -0.05 & 0.14 & -0.29 & -0.04 & 0.14 \\
\hline Return February 1-February 29, 2020 & 1,851 & -0.10 & 0.14 & -0.33 & -0.10 & 0.09 \\
\hline Return March 1- March 23, 2020 & 1,851 & -0.45 & 0.33 & -1.06 & -0.39 & -0.04 \\
\hline Return April 1-April 30, 2020 & 1,849 & 0.17 & 0.21 & -0.08 & 0.14 & 0.51 \\
\hline \multicolumn{7}{|l|}{ Liquidity components } \\
\hline Liquidity & 1,851 & 0.24 & 0.21 & 0.01 & 0.18 & 0.70 \\
\hline Undrawn CL-to-assets & 1,851 & 0.10 & 0.10 & 0.00 & 0.08 & 0.28 \\
\hline Cash-to-assets & 1,851 & 0.17 & 0.21 & 0.00 & 0.08 & 0.67 \\
\hline Short-term debt-to-assets & 1,851 & 0.03 & 0.05 & 0.00 & 0.02 & 0.12 \\
\hline \multicolumn{7}{|l|}{ Independent variables } \\
\hline $\log ($ Market cap $)$ & 1,851 & 7.55 & 1.93 & 4.46 & 7.54 & 10.87 \\
\hline Book-to-market ratio & 1,851 & 0.52 & 0.94 & -0.05 & 0.36 & 1.85 \\
\hline Equity beta (daily January $1-$ & & & & & & \\
\hline December 31,2019 ) & 1,851 & 1.15 & 0.49 & 0.33 & 1.14 & 1.99 \\
\hline Profitability & 1,851 & 0.27 & 0.23 & -0.04 & 0.26 & 0.65 \\
\hline $\begin{array}{l}\text { Momentum (January 1-December 31, } \\
\text { 2019) }\end{array}$ & 1,851 & 0.11 & 0.45 & -0.69 & 0.17 & 0.66 \\
\hline
\end{tabular}




\section{Table 7. Balance sheet liquidity and stock market performance}

The table shows results from cross-sectional regressions of stock returns in excess of the risk-free interest rate on firm characteristics. The dependent variables are stock returns over the January 1-March 23 period (column 1), January 1-January 31 period (column 2), February 1-February 29 period (column 3), March 1-March 23 period (column 4), and April 1-April 30 period (column 5). Panel A shows the results from regressions of stock returns on Liquidity. Liquidity is measured at the end of 2019. Control variables are from the asset pricing literature and include the firm's Equity Beta, the stock return in calendar year 2019 (Momentum), the Book-to-Market Ratio, $\log$ (Market Cap), and Profitability. Panel B shows the results from regressions of stock returns on the components of Liquidity. Table A1 in the appendix defines all variables. ${ }^{*} p<.1 ; * * p<.05 ; * * * p<.01$.

\section{A. Liquidity and stock returns}

\begin{tabular}{|c|c|c|c|c|c|}
\hline & $\begin{array}{c}(1) \\
\text { Return } \\
\text { January 1-March } \\
\text { 23, 2020 }\end{array}$ & $\begin{array}{c}(2) \\
\text { Return } \\
\text { January } 1-\text { January } \\
31,2020\end{array}$ & $\begin{array}{c}(3) \\
\text { Return } \\
\text { February 1- } \\
\text { February 29, 2020 }\end{array}$ & $\begin{array}{c}(4) \\
\text { Return } \\
\text { March 1-March } \\
\text { 23, 2020 }\end{array}$ & $\begin{array}{c}\text { (5) } \\
\text { Return } \\
\text { April 1-April 30, } \\
2020\end{array}$ \\
\hline Liquidity & $\begin{array}{c}0.582 * * * \\
(0.000)\end{array}$ & $\begin{array}{c}0.010 \\
(0.582)\end{array}$ & $\begin{array}{c}0.102 * * * \\
(0.000)\end{array}$ & $\begin{array}{c}0.471 * * * \\
(0.000)\end{array}$ & $\begin{array}{l}-0.002 \\
(0.934)\end{array}$ \\
\hline $\begin{array}{l}\text { Controls } \\
R^{2} \\
\text { Number obs. }\end{array}$ & $\begin{array}{l}\text { Yes } \\
.1831 \\
1,851\end{array}$ & $\begin{array}{c}\text { Yes } \\
.1329 \\
1,851\end{array}$ & $\begin{array}{l}\text { Yes } \\
.0548 \\
1,851 \\
\end{array}$ & $\begin{array}{c}\text { Yes } \\
.1314 \\
1,851\end{array}$ & $\begin{array}{c}\text { Yes } \\
.0661 \\
1,849\end{array}$ \\
\hline
\end{tabular}

\section{B. Liquidity components by time period}

\begin{tabular}{|c|c|c|c|c|}
\hline & $\begin{array}{c}(1) \\
\text { Return } \\
\text { February 1-March } \\
\text { 23, 2020 } \\
\end{array}$ & $\begin{array}{c}(2) \\
\text { Return } \\
\text { February 1-February } \\
29,2020 \\
\end{array}$ & $\begin{array}{c}\text { (3) } \\
\text { Return } \\
\text { March 1-March 23, } \\
2020 \\
\end{array}$ & $\begin{array}{c}(4) \\
\text { Return } \\
\text { April 1-April 30, } \\
2020 \\
\end{array}$ \\
\hline Undrawn CL-to-assets & $\begin{array}{c}0.096 \\
(0.258)\end{array}$ & $\begin{array}{c}-0.052 \\
(0.108)\end{array}$ & $\begin{array}{c}0.148 \\
(0.051)\end{array}$ & $\begin{array}{c}0.175^{* * *} \\
(0.001)\end{array}$ \\
\hline Cash-to-assets & $\begin{array}{c}0.631 * * * \\
(0.000)\end{array}$ & $\begin{array}{c}0.124 * * * \\
(0.000)\end{array}$ & $\begin{array}{c}0.506 * * * \\
(0.000)\end{array}$ & $\begin{array}{l}-0.032 \\
(0.210)\end{array}$ \\
\hline Short-term debt-to-assets & $\begin{array}{l}-0.469 \\
(0.126)\end{array}$ & $\begin{array}{l}-0.056 \\
(0.763)\end{array}$ & $\begin{array}{l}-0.413^{*} \\
(0.077)\end{array}$ & $\begin{array}{l}-0.238 \\
(0.289)\end{array}$ \\
\hline Controls & Yes & Yes & Yes & Yes \\
\hline$R^{2}$ & .1647 & .0708 & .1414 & .0760 \\
\hline Number obs. & 1,851 & 1,851 & 1851 & 1,849 \\
\hline
\end{tabular}




\section{Table 8. Balance sheet liquidity and stock market performance in 2007-09}

The table shows results from quarterly cross-sectional regressions of stock returns in excess of the risk-free interest rate on firm characteristics. The dependent variables are stock returns over the Q1 2007 to Q2 2009 period. Panel A shows the results from regressions of stock returns on Liquidity. Liquidity is measured at the end of 2006. Control variables are from the asset pricing literature and include the firm's Equity Beta, the stock return in the (precrisis) calendar year 2006 (Momentum), the Book-to-Market Ratio, log(Market Cap), and Profitability, all measured at the end of 2006. Panel B shows the results from regressions of stock returns on the components of liquidity. Table A1 in the appendix defines all variables. ${ }^{*} p<.1 ; * * p .05 ; * * * p<.01$

\section{A. Liquidity and stock returns}

\begin{tabular}{|c|c|c|c|c|c|c|c|c|c|c|}
\hline & $\begin{array}{c}(1) \\
2007 \text { Q1 }\end{array}$ & $\begin{array}{c}(2) \\
2007 \mathrm{Q} 2 \\
\end{array}$ & $\begin{array}{c}(3) \\
2007 \mathrm{Q} 3 \\
\end{array}$ & $\begin{array}{c}(4) \\
2007 \text { Q4 }\end{array}$ & $\begin{array}{c}(5) \\
2008 \text { Q1 }\end{array}$ & $\begin{array}{c}(6) \\
2008 \mathrm{Q} 2\end{array}$ & $\begin{array}{c}(7) \\
2008 \mathrm{Q} 3\end{array}$ & $\begin{array}{c}(8) \\
2008 \text { Q4 }\end{array}$ & $\begin{array}{c}(9) \\
2009 \text { Q1 }\end{array}$ & $\begin{array}{c}(10) \\
2009 \mathrm{Q} 2\end{array}$ \\
\hline Liquidity & $\begin{array}{c}-0.0001 \\
(0.996)\end{array}$ & $\begin{array}{c}0.1216^{* * *} \\
(0.000)\end{array}$ & $\begin{array}{c}0.1686^{* * *} \\
(0.000)\end{array}$ & $\begin{array}{c}0.0151 \\
(0.669)\end{array}$ & $\begin{array}{c}-0.0411 \\
(0.452)\end{array}$ & $\begin{array}{c}0.0802 * \\
(0.093)\end{array}$ & $\begin{array}{c}-0.0378 \\
(0.526)\end{array}$ & $\begin{array}{c}0.0864 \\
(0.259)\end{array}$ & $\begin{array}{c}0.1870 * * * \\
(0.000)\end{array}$ & $\begin{array}{c}-0.0124 \\
(0.740)\end{array}$ \\
\hline Controls & Yes & Yes & Yes & Yes & Yes & Yes & Yes & Yes & Yes & Yes \\
\hline$R^{2}$ & .0264 & .1647 & .1317 & .0622 & .0724 & .1265 & .1732 & .0939 & .1095 & .1894 \\
\hline Number obs. & 309 & 309 & 309 & 309 & 218. & 218 & 218 & 218 & 221 & 221 \\
\hline
\end{tabular}

B. Liquidity components and stock returns

\begin{tabular}{|c|c|c|c|c|c|c|c|c|c|c|}
\hline & $\begin{array}{c}(1) \\
2007 \mathrm{Q} 1 \\
\end{array}$ & $\begin{array}{c}(2) \\
2007 \mathrm{Q} 2 \\
\end{array}$ & $\begin{array}{c}(3) \\
2007 \text { Q3 }\end{array}$ & $\begin{array}{c}(4) \\
2007 \mathrm{Q} 4\end{array}$ & $\begin{array}{c}5) \\
2008 \text { Q1 } \\
\end{array}$ & $\begin{array}{c}(6) \\
2008 \mathrm{Q} 2 \\
\end{array}$ & $\begin{array}{c}(7) \\
2008 \text { Q3 }\end{array}$ & $\begin{array}{c}(8) \\
2008 \text { Q4 }\end{array}$ & $\begin{array}{c}(9) \\
2009 \text { Q1 }\end{array}$ & $\begin{array}{c}(10) \\
2009 \text { Q2 }\end{array}$ \\
\hline Undrawn CL-to-assets & $\begin{array}{c}-0.0005 \\
(0.987)\end{array}$ & $\begin{array}{c}0.1187 * * * \\
(0.000)\end{array}$ & $\begin{array}{c}0.1810 * * * \\
(0.000)\end{array}$ & $\begin{array}{l}-0.0214 \\
(0.566)\end{array}$ & $\begin{array}{c}-0.0444 \\
(0.453)\end{array}$ & $\begin{array}{l}0.0686 \\
(0.144)\end{array}$ & $\begin{array}{c}-0.0570 \\
(0.352)\end{array}$ & $\begin{array}{l}0.1052 \\
(0.135)\end{array}$ & $\begin{array}{c}0.1699 * * * \\
(0.000)\end{array}$ & $\begin{array}{l}-0.0308 \\
(0.375)\end{array}$ \\
\hline Cash-to-assets & $\begin{array}{c}-0.0481 \\
(0.546)\end{array}$ & $\begin{array}{c}0.1423 * * \\
(0.022)\end{array}$ & $\begin{array}{c}0.1293^{*} \\
(0.088)\end{array}$ & $\begin{array}{l}0.1363 \\
(0.120)\end{array}$ & $\begin{array}{l}-0.0910 \\
(0.519)\end{array}$ & $\begin{array}{c}-0.0164 \\
(0.906)\end{array}$ & $\begin{array}{l}0.1227 \\
(0.433)\end{array}$ & $\begin{array}{l}0.1262 \\
(0.548)\end{array}$ & $\begin{array}{c}0.5842 * * * \\
(0.001)\end{array}$ & $\begin{array}{l}0.0300 \\
(0.849)\end{array}$ \\
\hline Short-term debt-to-assets & $\begin{array}{c}-0.2976^{*} \\
(0.080)\end{array}$ & $\begin{array}{l}0.0229 \\
(0.850)\end{array}$ & $\begin{array}{c}-0.0433 \\
(0.836) \\
\end{array}$ & $\begin{array}{l}0.0220 \\
(0.910)\end{array}$ & $\begin{array}{r}-0.1390 \\
(0.497) \\
\end{array}$ & $\begin{array}{r}-0.3784 \\
(0.238) \\
\end{array}$ & $\begin{array}{l}0.1079 \\
(0.742) \\
\end{array}$ & $\begin{array}{l}0.2036 \\
(0.537) \\
\end{array}$ & $\begin{array}{c}0.7988^{* *} \\
(0.017) \\
\end{array}$ & $\begin{array}{r}-0.2334 \\
(0.349) \\
\end{array}$ \\
\hline $\begin{array}{l}\text { Controls } \\
R^{2} \\
\text { Number obs. }\end{array}$ & $\begin{array}{c}\text { Yes } \\
.0404 \\
309\end{array}$ & $\begin{array}{c}\text { Yes } \\
.1670 \\
309\end{array}$ & $\begin{array}{c}\text { Yes } \\
.1330 \\
309\end{array}$ & $\begin{array}{c}\text { Yes } \\
.0695 \\
309\end{array}$ & $\begin{array}{c}\text { Yes } \\
.0761 \\
218\end{array}$ & $\begin{array}{c}\text { Yes } \\
.1354 \\
218\end{array}$ & $\begin{array}{c}\text { Yes } \\
.1759 \\
218\end{array}$ & $\begin{array}{c}\text { Yes } \\
.0970 \\
218\end{array}$ & $\begin{array}{c}\text { Yes } \\
.1697 \\
221\end{array}$ & $\begin{array}{c}\text { Yes } \\
.1973 \\
221\end{array}$ \\
\hline
\end{tabular}




\section{Appendix}

\section{Table A1. Variable definitions}

\begin{tabular}{|c|c|c|}
\hline Variable name & Definition & Source \\
\hline AAA-A rating & A dummy equal to one if a firm's S\&P rating is equal to A- or higher & CapitalIQ \\
\hline BBB rating & A dummy equal to one if a firm's S\&P rating is equal to BBB-, BBB, or BBB+ & CapitalIQ \\
\hline Beta (36 months) & $\begin{array}{l}\text { Beta coefficient from a regression of monthly log excess returns on monthly market (S\&P 500) log excess returns over } \\
\text { (past) } 36 \text { months }\end{array}$ & CRSP \\
\hline Bond debt/assets & (Total Senior Bonds and Notes + Total Subordinated Bonds and Notes + Total Commercial Papers) / Total Assets & CapitalIQ \\
\hline Book-to-market ratio & Total Common Book Equity / Market Value of Equity & $\begin{array}{l}\text { Compustat North } \\
\text { America/CRSP }\end{array}$ \\
\hline CapEx-to-assets & Capital Expenditures / Total Assets $t-1$ & Compustat North America \\
\hline Cash / (Cash + Undrawn CL) & Cash \& Short-term Investments / (Cash \& Short-term Investments + Undrawn Revolving Credit) & CapitalIQ \\
\hline Cash-to-assets & Cash \& Short-term Investments / Total Assets & CapitalIQ \\
\hline Current ratio & Current Assets / Current Liabilities & CapitalIQ \\
\hline Dividend dummy & A dummy equal to one if a firm paid a common dividend in a given period and zero otherwise & Compustat North America \\
\hline Drawn CL / (Drawn CL + Undrawn CL) & Total Revolving Credit / (Total Revolving Credit + Undrawn Revolving Credit) & CapitalIQ \\
\hline Drawn CL / assets & Total Revolving Credit / Total Assets & CapitalIQ \\
\hline EBITDA-to-assets & EBITDA / Total Assets & CapitalIQ \\
\hline Equity beta & $\begin{array}{l}\text { Beta coefficient from a regression of daily log excess returns on daily market (S\&P 500) log excess returns from } \\
\text { January } 1 \text { to December } 31,2019\end{array}$ & CRSP \\
\hline Equity issuances/assets & (Issuance of Common Stock + Issuance of Preferred Stock) / Total Assets & CapitalIQ \\
\hline IG rating & A dummy equal to one if a firm's S\&P rating is equal to BBB- or higher & CapitalIQ \\
\hline Leverage & (Total long-term Debt + Current Debt in Total Debt) / Total Assets & Compustat North America \\
\hline Liquidity & (Undrawn Revolving Credit + Cash \& Short-term Investments - Current Portion of long-term Debt) / Total Assets & CapitalIQ \\
\hline $\log ($ Cash $)$ & $\log ($ Cash \& Short-term Investments $)$ & CapitalIQ \\
\hline $\log ($ Market cap) & $\log$ (Market value of equity) & CRSP \\
\hline $\log$ (Total assets) & $\log$ (Total assets) & CapitalIQ \\
\hline $\log ($ Total drawdown) & $\log$ (Total drawdowns) from March 1 to June 9, 2020 & LCD \\
\hline Loss dummy & A dummy equal to one if a firm's net income was below zero in a given period and zero otherwise & Compustat North America \\
\hline Momentum (Jan. 1-Dec. 31, 2019) & Sum of log excess returns from January 1 to December 31,2019 & CRSP \\
\hline NonIG rating & A dummy equal to one if a firm's $\mathrm{S} \& \mathrm{P}$ rating is equal to $\mathrm{BB}$ or lower & CapitalIQ \\
\hline Payouts/assets & (Repurchases of Preferred Stock + Common Dividends Paid) / Total Assets & CapitalIQ \\
\hline Profitability & Gross Profit / Total Assets & Compustat North America \\
\hline R\&D-to-sales & Research \& Development Expense / Sales (Net) & Compustat North America \\
\hline Rated & A dummy equal to one if a firm has a S\&P rating in CapitalIQ & CapitalIQ \\
\hline Return Jan. 1-Mar. 23, 2020 & $\begin{array}{l}\text { Cumulative stock return from January } 1 \text { to March } 23,2020 \text {; log excess returns are calculated as the } \log \left(1+r-r_{f}\right) \text {, where } \\
r \text { is the simple daily return (based on the daily closing price, adjusted for total return factor and daily adjustment factor), } \\
\text { and } r_{f} \text { is the } 1 \text {-month daily Treasury-bill rate }\end{array}$ & CRSP \\
\hline Return Jan. 1-Jan. 31, 2020 & Cumulative stock return from January 1 to January 31,2020 & CRSP \\
\hline Return Feb. 1-Feb. 29, 2020 & Cumulative stock return from February 1 to February 29, 2020 & CRSP \\
\hline Return Mar. 1-Mar. 23, 2020 & Cumulative stock return from March 1 to March 23, 2020 & CRSP \\
\hline
\end{tabular}




\begin{tabular}{|c|c|c|}
\hline Variable name & Definition & Source \\
\hline Return 2007 Q1-2009 Q4 & Cumulative stock return over the respective quarter & CRSP \\
\hline Short-term debt-to-assets & Current portion of long-term debt/total assets & CapitalIQ \\
\hline Tangible assets/assets & Net property, plant, and equipment/total assets & CapitalIQ \\
\hline Term loans/assets & Total term loans/total assets & CapitalIQ \\
\hline Total debt/assets & Total debt/total assets & CapitalIQ \\
\hline Undrawn CL-to-assets & Undrawn revolving credit/total assets & CapitalIQ \\
\hline z-score & Altman z-score & Altman 1986; CapitalIQ \\
\hline$\Delta$ Bond debt/asset $t_{-1}$ & 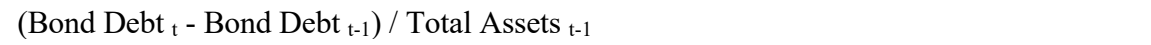 & CapitalIQ \\
\hline$\Delta$ Credit line usage & $[\text { Drawn CL / (Drawn CL + Undrawn CL) }]_{\mathrm{t}}-[$ Drawn CL / (Drawn CL + Undrawn CL $\left.)\right]_{\mathrm{t}-1}$ & CapitalIQ \\
\hline$\Delta$ Drawn CL/asset $_{\mathrm{t}-1}$ & $\left(\right.$ Drawn $C L_{t}-$ Drawn $\left.C L_{t-1}\right) /$ Total Assets $t-1$ & CapitalIQ \\
\hline$\Delta \log$ (Cash-to-assets) & $\log ($ Cash-to-Assets $t)-\log ($ Cash-to-Assets $\mathrm{t}-1)$ & CapitalIQ \\
\hline$\Delta$ Term loans/asset ${ }_{t-1}$ & (Term Loans $_{\mathrm{t}}-$ Term Loans $_{\mathrm{t}-1}$ ) / Total Assets $\mathrm{t}_{-1}$ & CapitalIQ \\
\hline
\end{tabular}

